In cooperation with the Kentucky Transportation Cabinet-Department of Highways

\title{
Estimating Mean Annual Streamflow of Rural Streams in Kentucky
}

Water-Resources Investigations Report 02-4206

U.S. Department of the Interior

U.S. Geological Survey 
U.S. Department of the Interior

U.S. Geological Survey

\section{Estimating Mean Annual Streamflow of Rural Streams in Kentucky}

By Gary R. Martin

Water-Resources Investigations Report 02-4206

In cooperation with the Kentucky Transportation CabinetDepartment of Highways 


\section{U.S. DEPARTMENT OF THE INTERIOR \\ GALE A. NORTON, Secretary}

\section{U.S. GEOLOGICAL SURVEY}

Charles G. Groat, Director:

Any use of trade, product, or firm names is for descriptive purposes only and does not imply endorsement by the U.S. Government.

For additional information write to:

District Chief, Kentucky District

U.S. Geological Survey

9818 Bluegrass Parkway

Louisville, KY 40299-1906

http://wwwdkylsv.er.usgs.gov
Copies of this report can be purchased from:

U.S. Geological Survey

Branch of Information Services

Box 25286

Denver, CO 80225-0286 


\section{CONTENTS}

Abstract

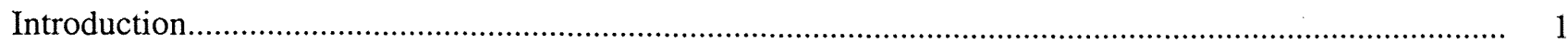

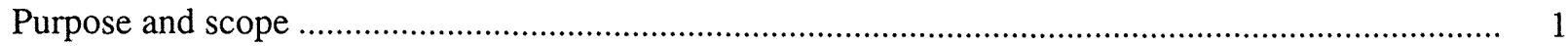

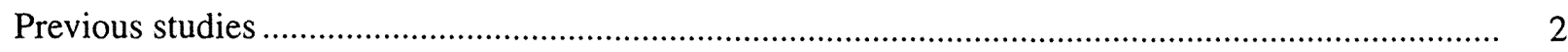

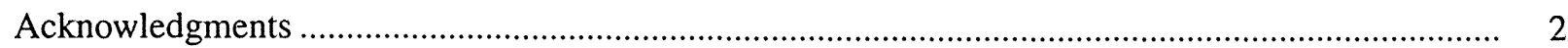

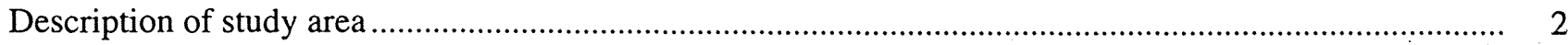

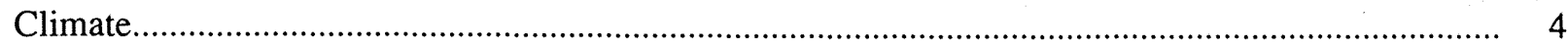

Physiography and geology ........................................................................................................ 4

Compilation and review of streamflow data ……………............................................................... 8

Mean annual streamflow estimates for gaged stream sites ...................................................................... 8

Development of the technique for estimating mean annual streamflow for ungaged, rural stream sites ........ 10

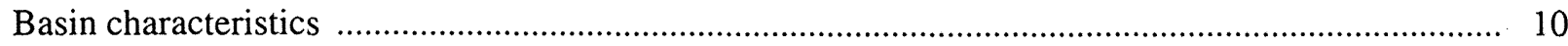

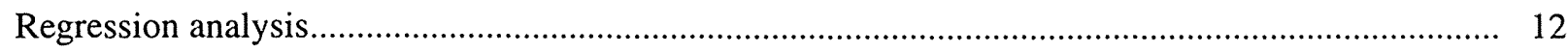

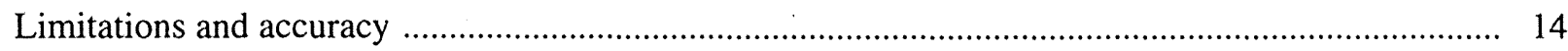

Procedures for estimating mean annual streamflow at stream sites in Kentucky ..................................... 15

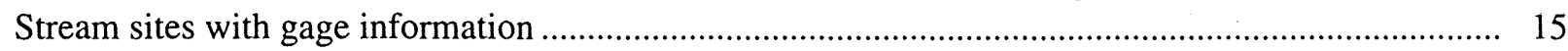

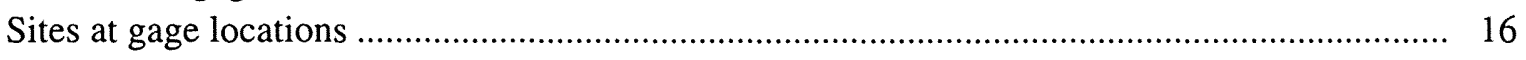

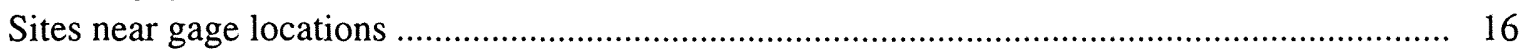

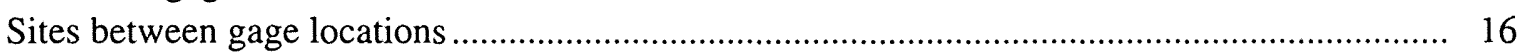

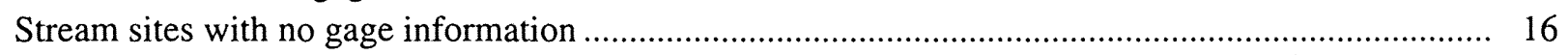

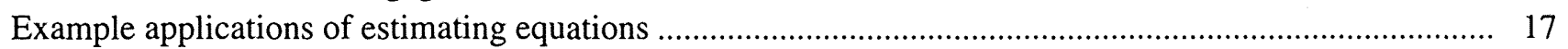

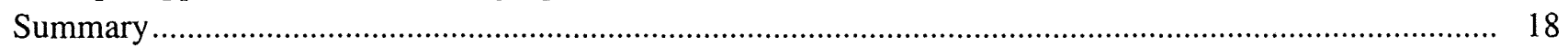

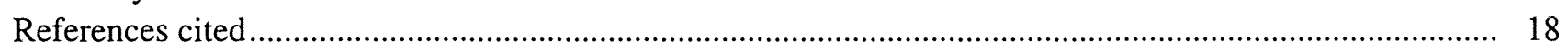

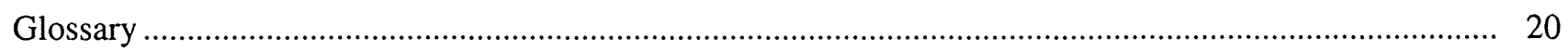

\section{FIGURES}

1-5. Maps showing:

1. Major drainage basins in Kentucky .................................................................................. 3

2. Shaded-relief image of landforms in Kentucky ................................................................... 5

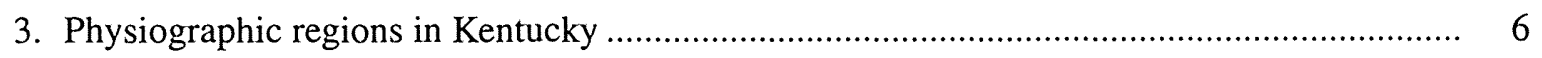

4. Generalized carbonate areas and surficial karst development in Kentucky ............................. 7

5. Locations of continuous-record streamflow-gaging stations in Kentucky and surrounding states for which data are presented in this report

6. Graph showing comparison of measured mean annual streamflow and mean annual streamflow estimated by use of the three-variable regression equation for the 170 continuous-record streamflow-gaging stations in Kentucky and surrounding States used in the regression 


\section{TABLES}

1. Continuous-record streamflow-gaging stations used in the study, selected basin characteristics, periods of record used in the analysis, corresponding mean annual flows, and selected reservoirs and diversions in the basin for Kentucky and surrounding States

2. Equations (derived by generalized-least-squares regression) for estimating mean annual streamflow in Kentucky

\section{CONVERSION FACTORS AND VERTICAL DATUM}

\section{CONVERSION FACTORS}

\begin{tabular}{rll}
\hline Multiply & By & To obtain \\
\hline inch (in.) & & millimeter \\
foot (ft) & 25.4 & meter \\
mile (mi) & 0.3048 & kilometer \\
square mile $\left(\mathrm{mi}^{2}\right)$ & 1.609 & square kilometer \\
cubic foot per second $\left(\mathrm{ft}^{3} / \mathrm{s}\right)$ & 2.590 & cubic meter per second \\
\hline
\end{tabular}

Temperature in degrees Fahrenheit $\left({ }^{\circ} \mathrm{F}\right)$ may be converted to degrees Celsius $\left({ }^{\circ} \mathrm{C}\right)$ as follows:

$$
{ }^{\circ} \mathrm{C}=\left({ }^{\circ} \mathrm{F}-32\right) / 1.8
$$

\section{VERTICAL DATUM}

Sea level: In this report "sea level" refers to the National Geodetic Vertical Datum of 1929 (NGVD of 1929)—a geodetic datum derived from a general adjustment of the first-order level nets of both the United States and Canada, formerly called Sea Level Datum of 1929. 


\title{
Estimating Mean Annual Streamflow of Rural Streams in Kentucky
}

\author{
By Gary R. Martin
}

\section{Abstract}

Mean annual streamflow $\left(Q_{a}\right)$, defined as the mean of the series of annual mean streamflow values, was determined for selected rural stream sites in Kentucky. Streamflow data for the available period of record through the 1999 water year (October 1, 1998-

September 30, 1999) at 235 continuous-record streamflow-gaging stations with at least 5 years of record located in and adjacent to Kentucky were used in the analysis. Record-extension procedures were applied for selected gaging stations to reduce time-sampling error and, thus, improve estimates of the long-term $Q_{a}$.

Techniques to estimate the $Q_{a}$ at ungaged stream sites in Kentucky were developed. One-, two-, and three-variable regression equations that included total drainage area, station latitude minus 36 degrees, and mean basin elevation as explanatory variables were developed by use of ordinary- and generalized-least-squares regression. The three-variable regression equation has an approximate average standard error of prediction of 13.7 percent. The one- and two-variable equations exhibit geographical biases, and the indicated standard errors of prediction may poorly estimate the true prediction errors, depending upon the location in the State. Therefore, the three-variable equation should be used for estimating mean annual streamflow of rural streams in Kentucky whenever possible.

\section{INTRODUCTION}

The U.S. Geological Survey (USGS) has collected continuous-record streamflow-gaging data in Kentucky since 1907 (Beaber, 1970); other agencies collected such data in Kentucky as early as 1890. Statistical characteristics of the streamflow data, such as the mean annual streamflow, are needed by water-resource managers and engineers for design of hydraulic structures constructed in the riverine environment.

Resource limitations make it unfeasible for the collection of data on every stream and at every stream site where streamflow characteristics may be needed; therefore, techniques for estimating the needed streamflow characteristics at ungaged stream sites have been developed. The USGS, in cooperation with the Kentucky Transportation Cabinet-Department of Highways, compiled the available continuous-record streamflow-gaging station data, computed the $Q_{a}$ for these gaged stream sites, and developed regional equations for estimating $Q_{a}$ at ungaged rural stream sites on the basis of selected drainage-basin characteristics.

\section{Purpose and Scope}

The purpose of this report is to provide (1) $Q_{a}$ values at continuous-record streamflowgaging stations having 5 or more years of record through the 1999 water year and (2) procedures for estimating the $Q_{a}$ at rural ungaged stream sites where flows are not appreciably affected by local diversions. This report presents $Q_{a}$ values for 235 continuous-record streamflow-gaging stations in the study area. Procedures for estimating the $Q_{a}$ at ungaged stream sites are described and illustrated with example computations. 


\section{Previous Studies}

Mean annual streamflows in Kentucky have been investigated in various previous studies. Beaber (1970) analyzed streamflow-data needs and applications in Kentucky. Statistical multipleregression analyses were done to define relations between selected streamflow characteristics and drainage-basin characteristics. Various regression models to estimate mean annual streamflows at ungaged stream sites statewide were developed, including

$$
\begin{gathered}
Q_{a}=1.19 A^{1.02} \\
Q_{a}=1.22 A^{1.01} E^{0.10} \\
Q_{a}=0.290 A^{1.01} E^{0.25} I^{1.27} \\
Q_{a}=0.270 A^{1.01} E^{0.23} I^{1.36} S t^{-0.14}
\end{gathered}
$$

where,

$Q_{a}$ is the mean annual streamflow, in $\mathrm{ft}^{3} / \mathrm{s}$;

$A$ is the drainage area in $\mathrm{mi}^{2}$;

$E$ is the mean elevation of the basin, in thousands of feet above sea level;

$I$ is the maximum 24-hour, 2-year rainfall intensity, in inches; and

$S t$ is the area of lakes and ponds in percent of drainage area (plus 1).

The regression analyses provided estimates of the accuracy of the relations, which improved as the number of explanatory (regressor) variables and model complexity increased. The average standard error of estimate ranged from 14.8 percent for equation 1 to 12.1 percent for equation 4 .

Melcher and Ruhl (1984) computed mean annual streamflows for the available period of record through the 1982 water year. Results presented were for combined regulated and unregulated periods of record at those sites with regulated flows.

Wetzel and Bettandorff (1986) developed regression models for estimating streamflow characteristics, including $Q_{a}$, based on data for 629 streamflow-gaging stations in coal provinces covering parts of 11 States in the eastern United States, including the Eastern and Western Kentucky
Coal Field physiographic regions. The basin characteristics used as explanatory variables in these regression models for estimation of $Q_{a}$ included drainage area, mean annual precipitation, and mean basin elevation. The average standard error of estimate ranged from 35.7 percent for the drainagearea-only model to 17.1 percent for the model that included all three of these basin characteristics as explanatory variables. The model coefficients of determination $\left(\mathrm{R}^{2}\right)$ in log space ranged from 0.96 to 0.99 .

\section{Acknowledgments}

The author would like to thank the Kentucky Transportation Cabinet for its support of this work. The author also wishes to thank the many local, State, and Federal agencies that have cooperated in the operation and maintenance of streamflowgaging stations in Kentucky and surrounding States that were used as part of this study. The author wishes to express appreciation to the many other USGS employees who assisted with collection and analysis of streamflow data, measurement of basin characteristics, and preparation of this report.

\section{DESCRIPTION OF STUDY AREA}

The Commonwealth of Kentucky encompasses an area of $40,395 \mathrm{mi}^{2}$ in the eastcentral United States. The major drainage basins in Kentucky-Big Sandy, Licking, Kentucky, Salt, Cumberland, Green, and Tennessee Rivers-are tributaries of the Ohio and Mississippi Rivers (fig. 1). In a generalized water balance for Kentucky, approximately 60 percent of precipitation leaves drainage basins as evapotranspiration, and approximately 40 percent of precipitation leaves as direct runoff or shallow ground-water flow into the streams and rivers. Variations in climate, physiography, and geology cause localized variations in streamflow characteristics in Kentucky. 


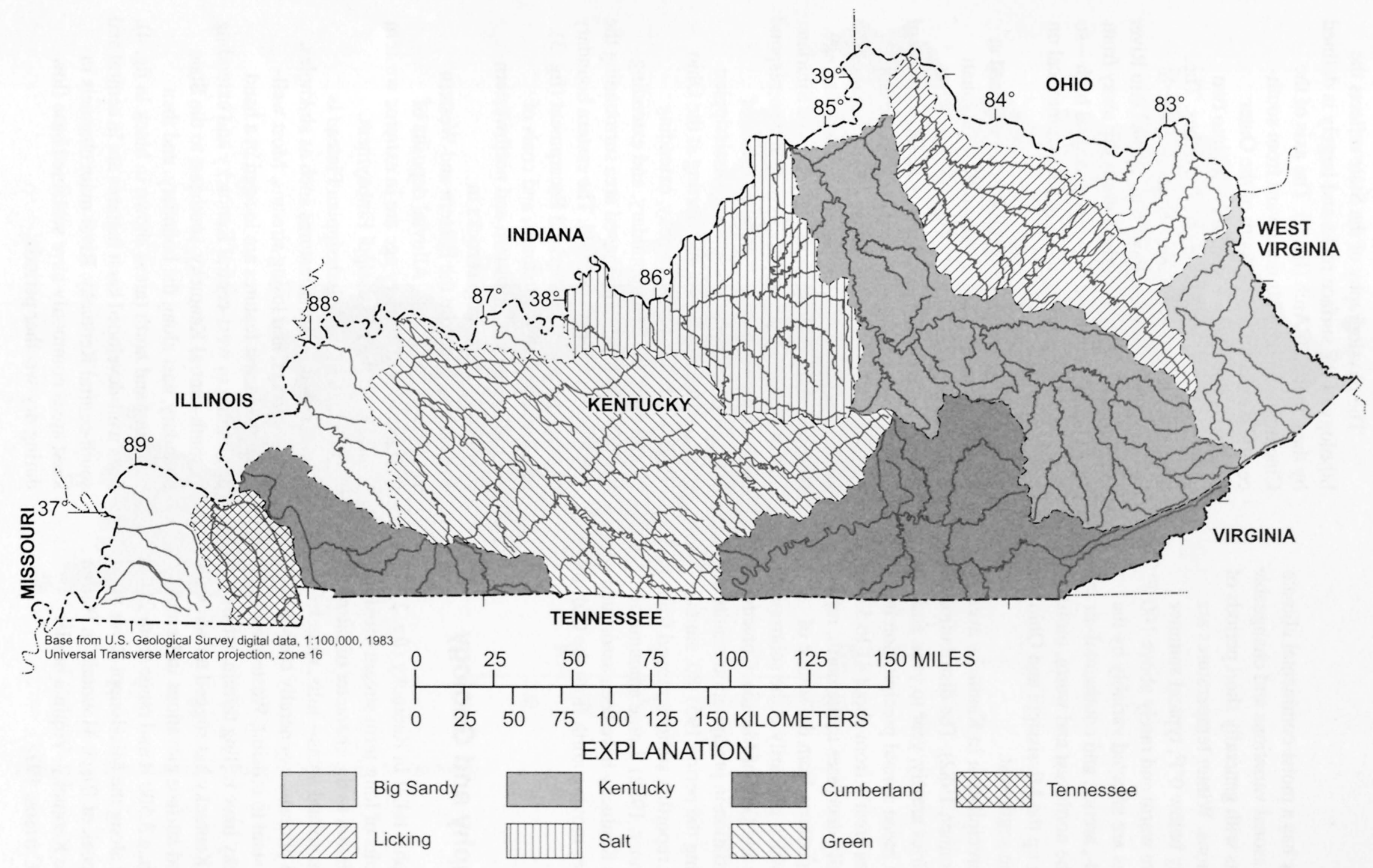

Figure 1. Major drainage basins in Kentucky. 


\section{Climate}

Kentucky has a moist-continental climate with distinct seasonal variations and changeable weather patterns with generally short periods of extreme conditions. Winter temperatures are moderate, rarely below $0^{\circ} \mathrm{F}$; typical summer temperatures are warm and rarely above $100^{\circ} \mathrm{F}$. The weather patterns are affected variably by the meeting of cold-, arctic-, and continental-air masses arriving from the northwest and warm, moist-air masses moving up the Mississippi and Ohio River Valleys from the southwest.

Annual precipitation in Kentucky averages about 47 in. (Conner, 1982). The distribution of precipitation varies areally, year to year, and seasonally. The mean annual precipitation in Kentucky ranges areally from about 41 to 53 in. Rainfall generally decreases to the north, reflecting the increase in distance from the source of precipitation, which primarily is the subtropical Atlantic Ocean and Gulf of Mexico. Considerable year-to-year variation in precipitation results in Kentucky. During the period 1951-80, annual precipitation at reporting stations ranged from 14.5 to 78.6 in. (Conner, 1982). Large amounts of precipitation in Kentucky have been associated with tropical cyclones moving north from the Gulf of Mexico.

\section{Physiography and Geology}

\section{Topographic relief in Kentucky (fig. 2)} reflects the results of long-term stream-erosional processes in relation to the character of the rock formations. The upland areas-hills, ridges, mountains, and plateaus-generally consist of formations resistant to erosion. Western and central parts of Kentucky have rolling terrain, whereas the eastern part of Kentucky has rugged terrain with high relief. Land-surface elevations in Kentucky vary by more than $3,500 \mathrm{ft}$ and range from $260 \mathrm{ft}$ above sea level along the Mississippi River to $4,145 \mathrm{ft}$ at the peak of Black Mountain in Harlan County near the Kentucky-Virginia border (McGrain and Currens, 1978).
The physiography of the State reflects the lithology of the surface rocks and largely is defined by the Cincinnati Arch (fig. 3). The axis of the Cincinnati Arch trends northward from southcentral Kentucky to just south of the Outer Bluegrass boundary where it divides into two branches-Kankakee and Findlay Arches. The branches approximately are parallel but are separated by approximately $25 \mathrm{mi}$ at the Ohio River (McFarland, 1950). Lithologic units dip away from the axis of the arch-a regional structural high-so that geologic features generally are symmetrical on each side of the arch.

Progressively younger rocks are exposed at the surface both east and west of the Cincinnati Arch. The oldest exposed rocks are part of the Jessamine Dome and adjacent areas; the location of this area corresponds approximately to the Inner Bluegrass region (fig. 3). These rocks consist of limestone, shale, and sandstone of Ordovician age. Narrow bands of shales and limestones of Silurian and Devonian age surround this area and correspond to The Knobs region. An expansive area of limestone of Mississippian age (Mississippian Plateaus Region) is exposed starting at the Ohio River in northeastern Kentucky, extending southwest to the State boundary, and extending northwest in a crescent-shaped area surrounding the Western Kentucky Coal Field. The eastern boundary of this area is the Cumberland Escarpment (fig. 3). Sandstones, shales, siltstones, and coals of Pennsylvanian age in eastern and northwestern Kentucky - the youngest rocks in Kentucky-compose the Eastern and Western Kentucky Coal Fields. Alluvial deposits of Cretaceous and Tertiary age are in extreme western Kentucky in the Mississippi Embayment.

Much of the Mississippian Plateau is characterized by karst features such as sinkholes, caves, springs, and losing streams. Most welldeveloped karst features are located in a band originating in west-central Kentucky and extending to south-central Kentucky, southeast to the State boundary, east along the boundary, and then northeast and north (areas shown in black in fig. 4). Less well-developed karst features are in central and south-central Kentucky. River main channels in karst areas commonly have sustained base flow during dry-weather periods. 


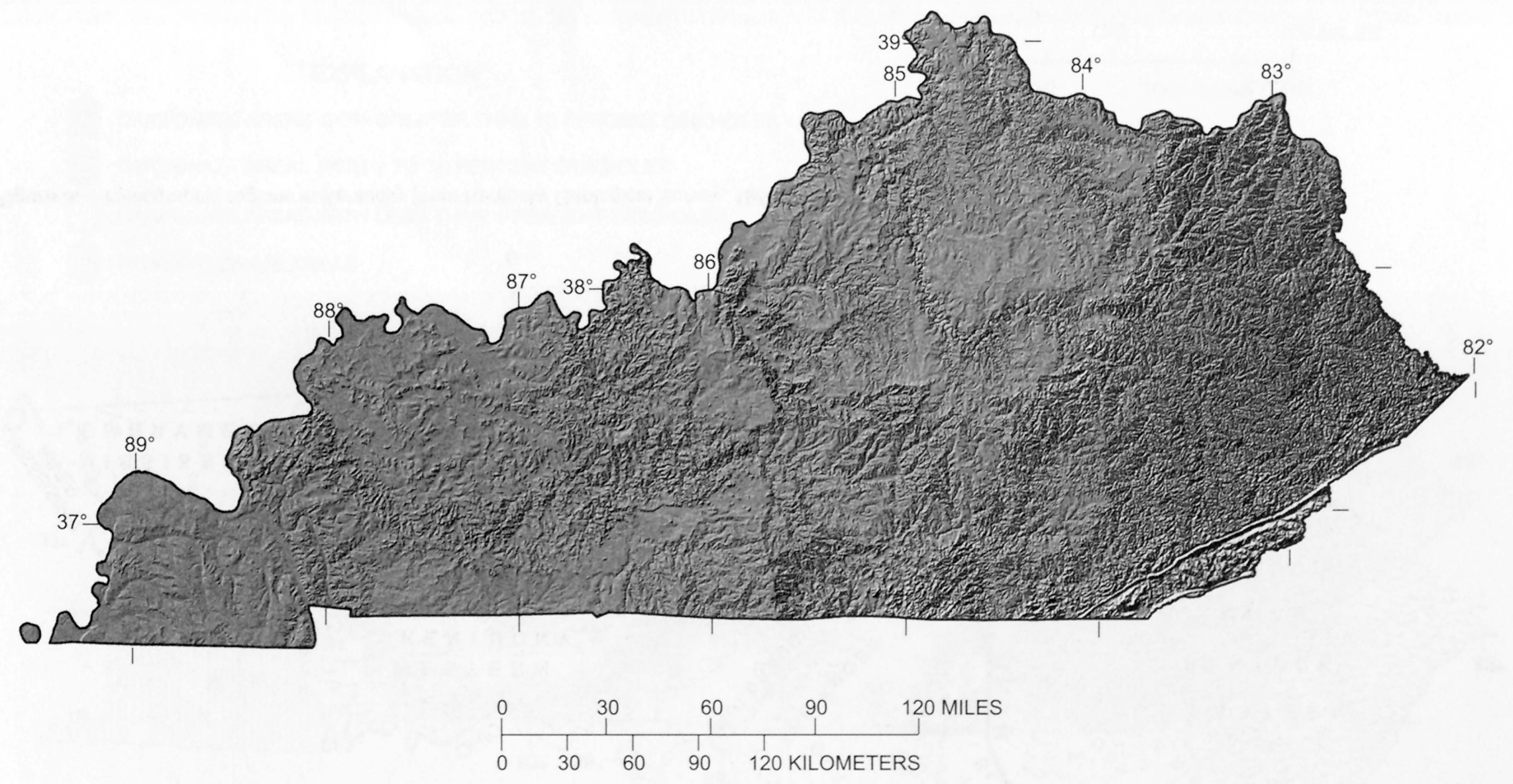

Figure 2. Shaded-relief image of landforms in Kentucky. 


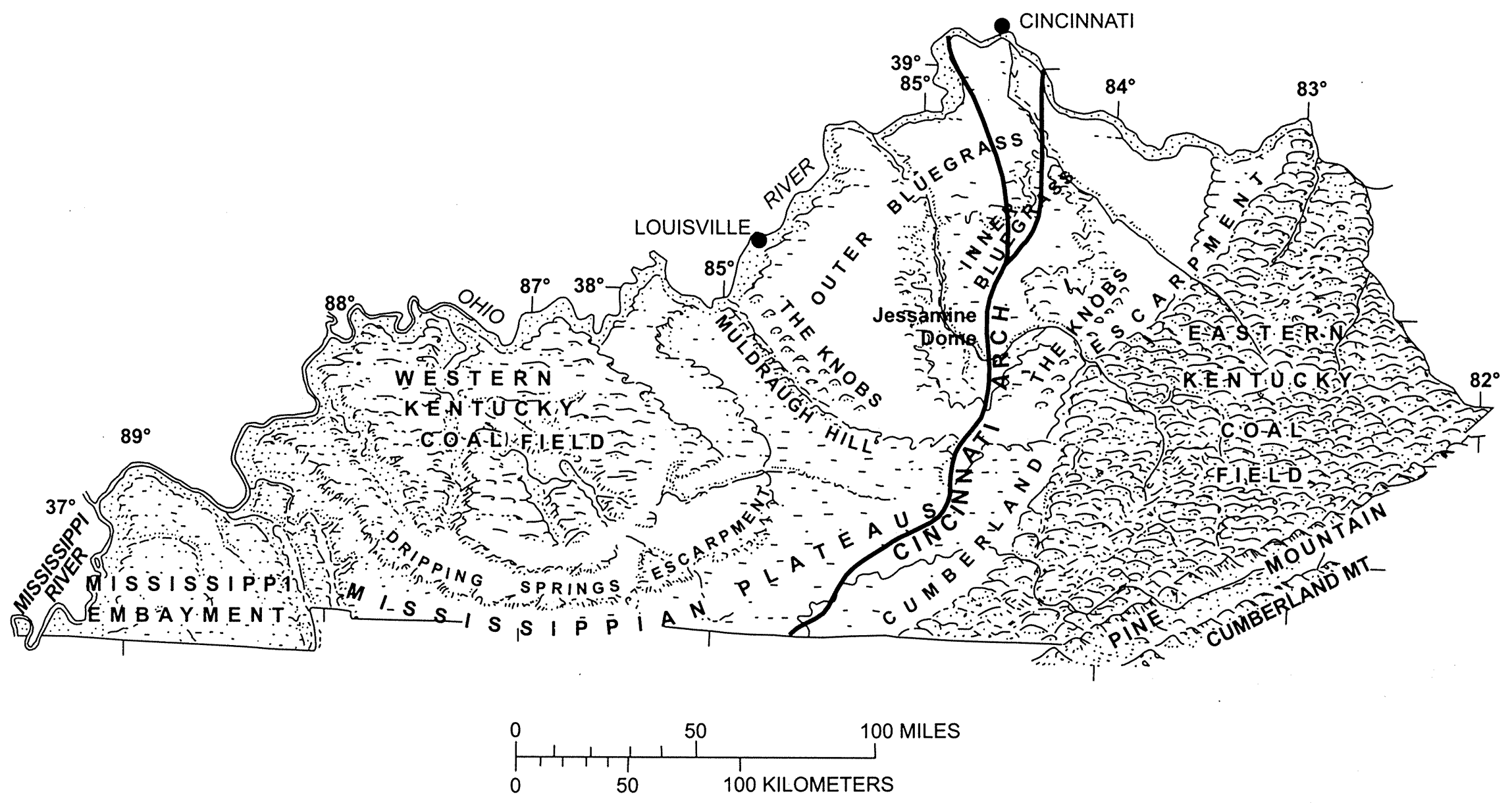

Figure 3. Physiographic regions in Kentucky [from Kentucky Geological Survey, 1980]. 


\section{EXPLANATION}

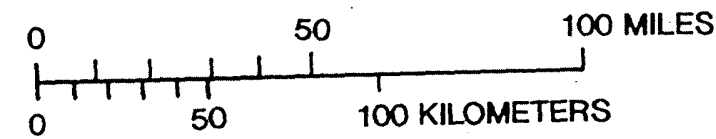

CARBONATE AREAS WITH GREATER THAN 10 PERCENT SINKHOLES

目 CARBONATE AREAS WTH 1 TO 10 PERCENT SINKHOLES

$\square$ CARBONATE AREAS WITH LESS THAN 1 PERCENT SINKHOLES

III. NONCARBONATE AREAS

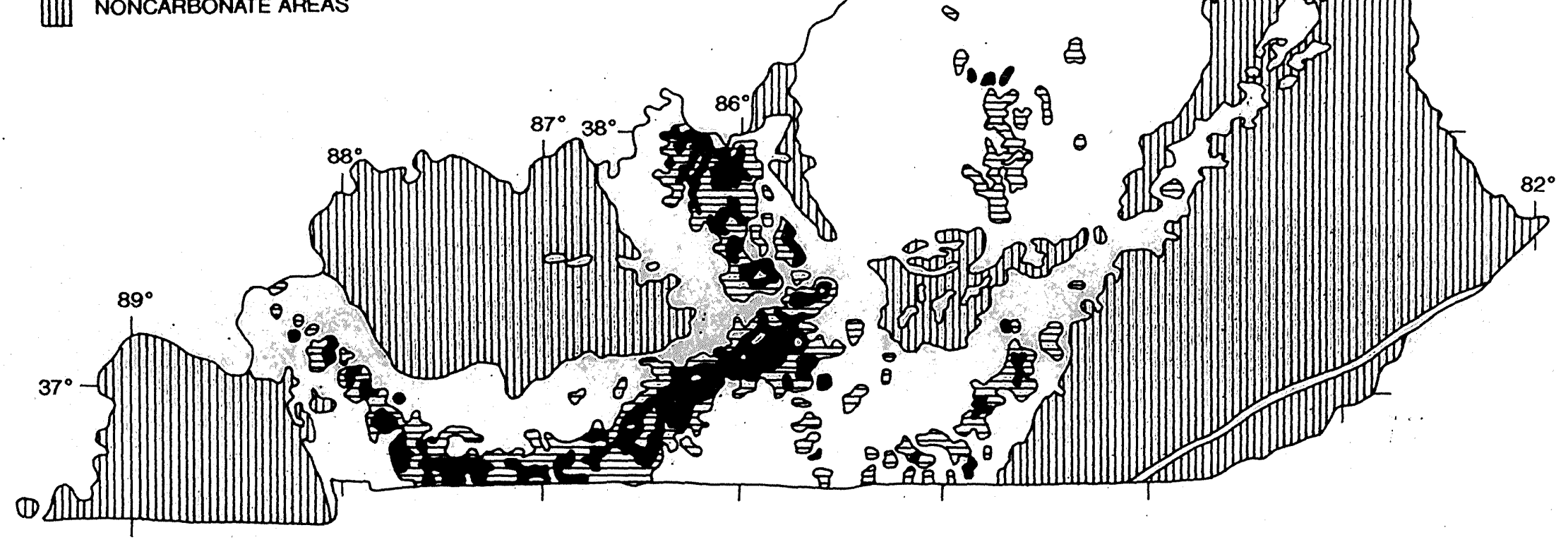

Figure 4. Generalized carbonate areas and surficial karst development in Kentucky [from Crawford and Webster, 1986]. 


\section{COMPILATION AND REVIEW OF STREAMFLOW DATA}

Daily mean streamflow data for 235 continuous-record streamflow-gaging stations located in Kentucky and adjacent states were retrieved by use of the USGS Automated Data Processing System (Bartholoma, 1997). The streamflow data in surrounding States were retrieved to provide additional information for use in the regionalization of $Q_{a}$ values. The data were checked and verified by comparing computed yearly and monthly summary statistics of the daily mean streamflows to published values (U.S. Geological Survey, 1958a, 1958b, 1964a, 1964b, 1962-65, 1966-75, and 1976-2000).

Annual mean streamflows at 235 stations (198 in Kentucky and 37 in surrounding States) were tested for trends $(p<=0.10)$ by use of the Kendall's Tau test, which indicated that 27 stations had an increasing trend in streamflow and 3 had a decreasing trend in streamflow. These trends appeared climate-related and consistent with reported trends for mid-range (median) flows in this region (Lins and Slack,1999). Precipitation-adjusted annual mean streamflows were approximated roughly as the residuals from regressions of annual mean streamflow with annual precipitation data (by water year; see Glossary for definition) at Louisville, Ky., which is centrally located in relation to the gaging stations in the data set. Kendall's Tau tests of these residuals indicated that 28 had trend: 19 with increasing trend and 9 with decreasing trend.

Daily mean streamflows at many gaging stations in Kentucky are affected by regulation and (or) local diversions. Regulation by multipurpose or flood-control reservoirs reduce peak flows and generally augment low flows on a seasonal time scale; however, when streamflows are averaged over an annual time step, as in the case of the annual mean streamflow statistic, regulation generally has no effect on this statistic when the volume of water stored is released during the same water year. Twosample statistical comparisons (Mathsoft, Inc., 1999a and 1999b) of pre- and post-regulation, precipitation-adjusted annual mean streamflow values (the residuals of the regression of annual mean streamflow with annual precipitation) downstream from some of the major reservoirs in Kentucky failed to indicate a significant difference in the sample means ( $p=0.05$ ).

Local diversions-localized transfers of water such as water-supply withdrawals or wastewater discharges-artificially decrease or increase streamflows within a reach. Local diversions are common near municipalities and in urban areas. The extent of alterations in natural streamflows caused by local diversions was reviewed based on available water-withdrawal and permitted-wastewaterdischarge data. (A.C. Downs, U.S. Geological Survey, written commun., 2002; and S. Bolssen, Kentucky Natural Resources and Environmental Protection Cabinet, Division of Water, written commun., 2002). Localized diversions were deemed minor in relation to $Q_{a}$ where available data indicated the flows diverted annually probably would not exceed 10 percent of $Q_{a}$.

\section{MEAN ANNUAL STREAMFLOW ESTIMATES FOR GAGED STREAM SITES}

Annual mean streamflows were computed from daily mean streamflows by use of the National Water Information System program DVMAS (Daily Values Monthly and Annual Statistics) (Bartholoma, 1997). The mean annual streamflow $\left(Q_{a}\right)$ is defined as

$$
Q_{a}=\left(\sum_{i=1}^{N_{a}} Q_{a i}\right) / N_{a},
$$

where

$$
\begin{aligned}
& Q_{a i} \quad \begin{array}{l}
\text { is annual mean streamflow for the } i \text { th } \\
\text { year and }
\end{array} \\
& N_{a} \quad \text { is the number of annual mean } \\
& \text { streamflows in the gaging station } \\
& \text { period of record. }
\end{aligned}
$$

The computed values of $Q_{a}$ at streamflowgaging stations having at least 5 years of record are shown in table 1 (back of report). Locations of these gaging stations are shown in figure 5 . 


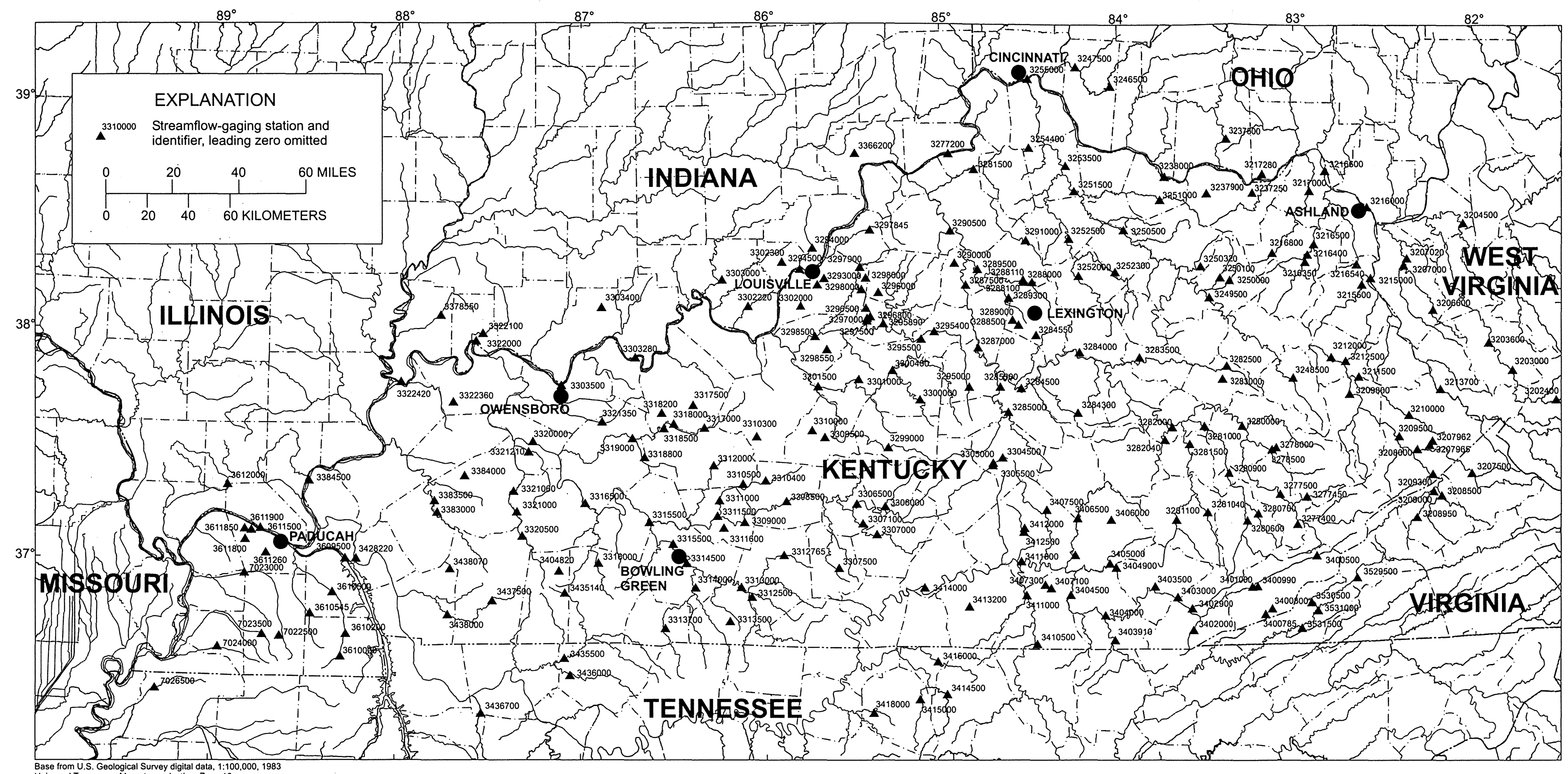

Figure 5. Locations of continuous-record streamflow-gaging stations in Kentucky and surrounding States for which data are presented in this report. (See table 1.) 
Streamflow statistics are subject to error associated with the particular time period sampled (time-sampling error). Gaged record may occur during either an abnormally wet or dry period, thus making it unrepresentative of long-term average climatic conditions. Time-sampling error decreases as record length increases. An example of the effects of time-sampling error is reflected in the $100 \mathrm{ft}^{3} / \mathrm{s}$ difference (reduction) of the computed $Q_{a}$ value at Barren River at Lock 1 at Greencastle (station 0331500) compared to the computed $Q_{a}$ value upstream at Barren River at Bowling Green (station 03314500) as shown in table 1.

Record-extension (augmentation) techniques may be used to reduce time-sampling error in streamflow values and statistics. Record extension is achieved by relating concurrent streamflows (and streamflow statistics) at a short-term and a nearby long-term (index) station that is hydrologically similar. The $Q_{a}$ at the index station and the relation between the concurrent daily mean streamflows at both stations may be used to provide an estimate of the long-term $Q_{a}$ at the short-term station. A mathematical record-extension technique, Maintenance of Variance Extension Type 1 (MOVE.1) as described by Hirsch (1982), was used in this study. The estimate was computed by use of log-transformed values of the concurrent nonzero daily mean streamflows as

$$
\log Q_{a(s)}=M_{s}+\left(\frac{S_{s}}{S_{l}}\right) \times\left(\log Q_{a(l)}-M_{l}\right),
$$

where

$$
\begin{gathered}
Q_{a(s)} \begin{array}{l}
\text { is the estimated long-term } Q_{a} \text { for the } \\
\text { short-term station; }
\end{array} \\
Q_{a(l)} \quad \begin{array}{r}
\text { is the } Q_{a} \text { for the long-term station; } \\
M_{s}, M_{l} \quad \begin{array}{l}
\text { are the mean of the log-transformed daily } \\
\text { mean streamflows for the concurrent } \\
\text { period at the short- and long-term }
\end{array} \\
\text { stations, respectively; and }
\end{array} \\
S_{s}, S_{l} \quad \begin{array}{l}
\text { are the standard deviations of the log- } \\
\text { transformed daily mean streamflows } \\
\text { for the concurrent period at the short- } \\
\text { and long-term stations, respectively. }
\end{array}
\end{gathered}
$$

MOVE.1 was applied to improve $Q_{a}$ estimates for Ohio River main-stem stations only (table 1). The two long-term index stations on the Ohio River at Louisville, Ky. (03294500) and at Metropolis, Ill. (03611500) each had 71 full water years of record (1929-99). Stations designated "short-term" in equation 6 had fewer than 71 years of record. The adjustments reduced time-sampling errors and improved consistency in $Q_{a}$ and drainage-areastandardized values of $Q_{a}$ along the river.

\section{DEVELOPMENT OF THE TECHNIQUE FOR ESTIMATING MEAN ANNUAL STREAMFLOW FOR UNGAGED, RURAL STREAM SITES}

A regression was used to develop regional equations for estimating $Q_{a}$ at ungaged, rural sites. Drainage-basin characteristics, including climate, affect streamflow patterns. Relations among selected basin characteristics and computed $Q_{a}$ were investigated by methods of linear correlation and multiple-linear regression.

\section{Basin Characteristics}

Various drainage-basin characteristics were tested for applicability in the regionalization of $Q_{a}$. Selection of basin characteristics for inclusion in exploratory scatter plots, linear correlation analysis, and subsequent multiple-linear-regression analysis was based on (1) the possible hydrologic importance of the characteristic in relation to the $Q_{a}$ statistic, (2) the availability of previously determined basin characteristics for the study basins, and (3) results of previous regionalization studies of other streamflow statistics (Beaber, 1970; Wetzel and Bettandorff, 1986; Choquette, 1988; Ruhl and Martin, 1991; and Martin and Ruhl, 1993).

Basin characteristics tested for significance in the regression analysis included the following:

total drainage area $(A)$, in square miles, the area measured in a horizontal plane that is enclosed by a drainage divide, measured by planimeter, digitized, or grid method from USGS 7.5-minute topographic quadrangle maps; 
contributing drainage area, in square miles, is the total drainage area excluding any parts characterized by internal drainage, such as by way of sinkholes in karst terrain; main-channel length, in miles, the length measured along the main stream channel from the station to the basin divide, following the longest tributary as determined from USGS 7.5-minute topographic quadrangle maps; main-channel slope, in feet per mile, computed as the difference in elevation between points located at 10 and 85 percent of the main-channel length from the gage, divided by the stream length between these two points, as determined from USGS 7.5-minute topographic quadrangle maps; basin length, in miles, the straight-line distance from the streamflow-gaging station to the basin divide (defined by the mainchannel length);

mean basin width, in miles, calculated by dividing the total drainage area by basin length;

basin shape, the ratio of basin length, in miles, squared to total drainage area, in square miles;

main-channel sinuosity, the ratio of mainchannel length, in miles, to basin length, in miles;

mean basin elevation $(E)$, in thousands of feet above sea level, computed as the average elevation of the basin from a 1:250,000-scale digital elevation model converted to a grid coverage in

ARC/INFO;

average basin elevation index, in thousands of feet above sea level, determined by averaging main-channel elevations at points 10 and 85 percent of the distance from a specified location on the main channel to the topographic divide, as determined from USGS 7.5-minute topographic quadrangle maps; storage area, in percent, plus 1.00 percent, that part of the contributing drainage area occupied by lakes, ponds, and swamps, as shown on USGS 7.5-minute topographic quadrangle maps, not including temporary storage as a result of detention basins or ponding at roadway embankments; mean annual precipitation, in inches, minus 30 in., estimated from Kentucky Department for Natural Resources and Environmental Protection (1979) and Conner (1982);

maximum 24-hour precipitation intensity, in inches, with recurrence intervals of 2 and 10 years (Hershfield, 1961);

maximum 24-hour precipitation intensity, in inches, occurring during the 30-year interval of 1951-80 (Glenn Conner, Kentucky Climate Center, written commun., 1986);

soils index, in inches ("S"; U.S. Department of Agriculture, 1969), is a measure of potential infiltration based on basin vegetative cover, soil infiltration rate, and soil water storage;

soil infiltration index, in inches per hour, is based on minimum infiltration rates for the U.S. Soil Conservation Service hydrologic soil groups (Musgrave, 1955) for soil series in Kentucky (U.S. Department of Agriculture, 1975 and 1984);

forested area, as a percentage of the contributing drainage area, plus

1.00 percent, measured from USGS

7.5-minute topographic quadrangle maps by use of the transparent-grid sampling method;

streamflow-recession index, defined as the number of days it takes base streamflow to decrease one log cycle, or one order of magnitude, as determined graphically from hydrograph plots of daily mean streamflow during representative periods of streamflow recession (Riggs, 1964; Bingham, 1982; and Ruhl and Martin, 1991);

streamflow-variability index, (Lane and Lei, 1950) at a station ("station" value) is computed as the standard deviation of the logarithms of the 19 discharges at 5-percent class intervals from 5 to 95 percent on the 
flow-duration (cumulative-frequency) curve (Searcy, 1959; and Dempster, 1990) of daily mean streamflow for the entire period of record; "mapped" values of variability index tested in the regression were computed as areally weighted average values from the regionalized variability index (Ruhl and Martin, 1991);

azimuth, measured in degrees from north of line defining basin length;

gaging-station latitude ( Lat $_{\mathbf{g}}$ ), in decimal degrees, minus $36.0^{\circ}$, commonly determined from USGS 7.5-minute topographic quadrangle maps; gaging-station longitude, in decimal degrees, minus $81.0^{\circ}$, commonly determined from USGS 7.5-minute topographic quadrangle maps;

drainage-basin centroid latitude, in decimal degrees minus $36.0^{\circ}$, determined in geographical information system (GIS) by means of the "centrallabels" command as applied to the basin-boundary polygons in ARC/INFO; and

drainage-basin centroid longitude, in decimal degrees, minus $81.0^{\circ}$, determined in a GIS as described for centroid latitude.

\section{Regression Analysis}

A multiple-linear-regression model was developed to relate $Q_{a}$ (dependent variable) to selected basin characteristics ("independent" or explanatory variables). Included in the regression analysis were 170 streamflow-gaging stations with at least 10 years of record where $Q_{a}$ was deemed not significantly affected by local diversions (identified as "minor" local diversions in table 1). The regression analysis included an exploratory phase using ordinary-least-squares (OLS) regression to select appropriate explanatory variables and a final phase using generalized-least-squares (GLS) regression. GLS regression compensates for differences in the variability and reliability of, and correlation among, the $Q_{a}$ estimates at stations included in the analysis.
Inspection of scatter plots showing relations among dependent and explanatory variables and plots of residuals from initial linear regressions indicated that logarithmic (base 10) transformation of the dependent and most of the explanatory variables would be appropriate. This transformation generally helped make the relations more linear and the residuals more uniform in variance about the regression line than before transformation. The relations between dependent and explanatory variables after transformation were consistent with the assumed linear form of the model.

The general form of the regression models developed in this study is

$$
\begin{aligned}
& \log \left(Q_{a}\right)=b_{o}+b_{1} \log X_{1}+b_{2} \log X_{2}+ \\
& \ldots+b_{n} \log X_{n}+\varepsilon,
\end{aligned}
$$

where

$$
\begin{aligned}
& Q_{a} \text { is mean annual streamflow, } \\
& b_{o} \text { is a constant, }
\end{aligned}
$$

$b_{i}(i=1$ to $n)$ is the regression coefficient for the $i$ th explanatory variable,

$X_{i}(i=1$ to $n)$ is the $i$ th explanatory variable,

$\varepsilon \quad$ is a random error component, and

$n \quad$ is the total number of explanatory variables.

The algebraically equivalent form when the $\log$ (base 10) transformation is used and when the equation is re-transformed to the original units is

$$
Q_{a}=10^{b o} X_{1}^{b 1} X_{2}^{b 2} \ldots X_{n}^{b r}
$$

The alternative OLS regression models were generated by all-possible-regression and stepwiseregression procedures (Statistical Analysis System Institute, Inc., 1985) using the prospective explanatory variables listed in "Basin Characteristics." Various factors were considered in evaluating alternative regression models, including (1) the coefficient of determination, the proportion of the variation in the response variable explained by the regression equation; (2) the standard error of the estimate, a measure of model-fitting error; (3) the prediction sum of squares (PRESS) statistic, a measure of model-prediction error; (4) the statistical significance of each alternative 
explanatory variable; (5) potential multicollinearity as indicated by the correlation of explanatory variables and the value of the variance inflation factor (Montgomery and Peck, 1982); (6) the effort and modeling benefit of determining the values of each additional explanatory variable; and (7) the hydrologic validity of the signs and magnitudes of the regression exponents.

The best one-, two-, and three-variable OLS regression models included total drainage area $(A)$, latitude of the gaging station minus $36^{\circ}\left(\mathrm{Lat}_{\mathrm{g}} \mathrm{-36}\right.$ ), and mean basin elevation $(E)$ in thousands of feet above sea level as explanatory variables. The drainage-area-only model accounts for a large part of the variability of $Q_{a}$; however, the drainage-areaonly model exhibits geographical bias, which was reduced progressively by adding the second and third explanatory variables to the regression models. The locational variable, $L a t_{g}$, may serve to integrate and index statewide variations in precipitation and evapotranspiration. Mean basin elevation also may serve as an index to a combination of other factors that are difficult to evaluate, such as radiation, temperature, wind, vegetation, and basin relief, which can cause streamflow variations (Thomas and Benson, 1970).

The OLS regression coefficients all are statistically different from zero ( $p$-value less than $0.01)$. Regression residuals were analyzed to (1) identify outliers and high-leverage stations for examination, (2) confirm normality and homogeneity of variance, and (3) identify and remedy geographic bias.

The regression models (table 2) were finalized by use of GLS regression techniques
(Stedinger and Tasker, 1985; and Tasker and Stedinger, 1989), which were implemented in the computer program GLSNET (G.D. Tasker, K.M. Flynn, A.M. Lumb, and W.O. Thomas, U.S. Geological Survey, written commun., 1995). Two major assumptions of OLS regression commonly are violated in regression of streamflow statistics: (1) the errors of the streamflow statistic are homogeneous among the observations and (2) the observations statistically are independent. Error in streamflow statistics vary with the length of record, which differs among the gaging stations, and streamflows at the set of gaging stations are correlated because the same climatic conditions and weather events generally affect most of the streams within a hydrologic region.

Stedinger and Tasker $(1985,1986)$ have shown that where streamflow records are of widely varying length and concurrent flows at different sites are highly correlated, GLS regression provides more accurate estimates of the regression coefficients, better estimates of the accuracy of the regression coefficients, and almost unbiased estimates of the model error when compared to OLS regression. GLS regression gives more weight to long-term gaging stations (with less time-sampling error) than short-term gaging stations and more weight to stations where flows are least correlated to flows at other gaging stations. GLS regression procedures use weighting matrices to proportionately account for the cross-correlation of streamflows and for the variations in time-sampling error of the streamflow statistic among the gaging stations.

Table 2. Equations (derived by generalized-least-squares regression) for estimating mean annual streamflow in Kentucky

$\left[Q_{a}\right.$, mean annual streamflow in cubic feet per second; $A$, total drainage area, in square miles; Lat $_{g}$, latitude of the gage, or basin outfall, in decimal degrees; $E$, mean basin elevation, in thousands of feet above sea level; --, not applicable]

\begin{tabular}{|c|c|c|c|c|c|}
\hline \multirow[b]{2}{*}{ Equations } & \multicolumn{3}{|c|}{ Range of explanatory variable } & \multirow{2}{*}{$\begin{array}{c}\text { Approximate } \\
\text { average } \\
\text { standard } \\
\text { error of } \\
\text { prediction } \\
\text { (percent) }\end{array}$} & \multirow{2}{*}{$\begin{array}{l}\text { Average } \\
\text { equivalent } \\
\text { years of } \\
\text { record }\end{array}$} \\
\hline & $A$ & Lat $_{g}$ & $E$ & & \\
\hline$Q_{a}=1.38 A^{1.01}$ & $0.67-2,762$ & -- & -- & 15.8 & 10.9 \\
\hline$Q_{a}=1.42 A^{1.01}\left(\text { Lat }_{g}-36\right)^{-0.18}$ & $.67-2,762$ & $36.341-39.140$ & -- & 14.2 & 14.9 \\
\hline$Q_{a}=1.39 A^{1.00}\left(\text { Lat }_{g}-36\right)^{-0.15} E^{0.12}$ & $.67-2,762$ & $36.341-39.140$ & $0.391-2.414$ & 13.7 & 15.4 \\
\hline
\end{tabular}


The cross-correlations were estimated as an empirical, best-graphical-fit function of the distance between pairs of long-term gaging stations having at least 50 years of concurrent record. GLS regression required matrices of the mean, standard deviation, and skew of the annual mean streamflows associated with the matrix of the $Q_{a}$. A regional estimate of the standard deviations of annual mean streamflows independent of the $Q_{a}$ estimating equation was developed within GLSNET by use of regression of the standard deviation against drainage area and mean basin elevation. A skew matrix was estimated by use of the observed skew of the series of annual mean streamflows at the gaging stations. The length of record at each gaging station was used as a measure of the reliability of the $Q_{a}$ estimates. GLSNET enables partitioning of total regressionmodel error into model error and sampling error, which consists of both time- and space-sampling error: Model error arises from limitations of the model formulation, and it cannot be reduced by additional data collection. Time- and space-sampling error, however, are reduced through additional data collection by extending the period of data collection and by expanding the variety of basin characteristics of the sites where data are collected, respectively.

\section{Limitations and Accuracy}

The one-, two-, and three-variable regional regression models for estimating $Q_{a}$ at ungaged stream sites have varying limitations and accuracies (table 2). As indicated previously, the one- and twovariable equations exhibit geographical biases, and the indicated standard errors of prediction may poorly estimate the true prediction errors, depending on the location in the State. The one- and twovariable models are suitable for initial approximate $Q_{a}$ estimates; however, the three-variable equation should be used whenever possible.

The regional regression models are applicable to rural streams in Kentucky that are not appreciably affected by local diversions, which commonly are associated with urban development. Caution is warranted when applying the regression models in areas where streamflows are affected by hydrologic discontinuities such as large springs and sinks common to karst terrain in areas underlain by limestone (see fig. 4). Streamflows in these areas may vary unpredictably in karst drainageways. It may be difficult (if not impossible) to determine an accurate basin drainage area in karst terrain solely on the basis of topographic divides.

The regression model was developed by use of basin characteristics within a certain range of values. Drainage areas $(A)$ of stations used in the regression analysis ranged from 0.67 to $2,762 \mathrm{mi}^{2}$, gage latitudes $\left(L a t_{g}\right)$ ranged from 36.341 to $39.140^{\circ}$, and mean basin elevations $(E)$ ranged from 0.391 to 2.414 in thousands of feet above sea level.

Application of the regression models for $Q_{a}$ estimates in basins outside these ranges is an extrapolation; therefore, these models probably should not be applied for this situation.

The standard error of prediction (of $\log Q_{a}$ ) of the three-variable model-a measure of the accuracy of the regression estimates compared to observed data for stations excluded from the regression-is 13.7 percent. Standard error of prediction was estimated as the square root of the PRESS divided by the error degrees of freedom (Statistical Analysis System Institute, Inc., 1985; Montgomery and Peck, 1982; and Choquette, 1988). The procedure used for computing PRESS is considered a form of data splitting and can be applied as a model-validation tool. The accuracy of the three-variable model predictions for ungaged sites similar to those used in the regression could be expected to compare favorably to the standard error of prediction. A scatter plot of the values of $Q_{a}$ computed from the streamflow-gaging station data and values computed using the regression model are shown in figure 6. 


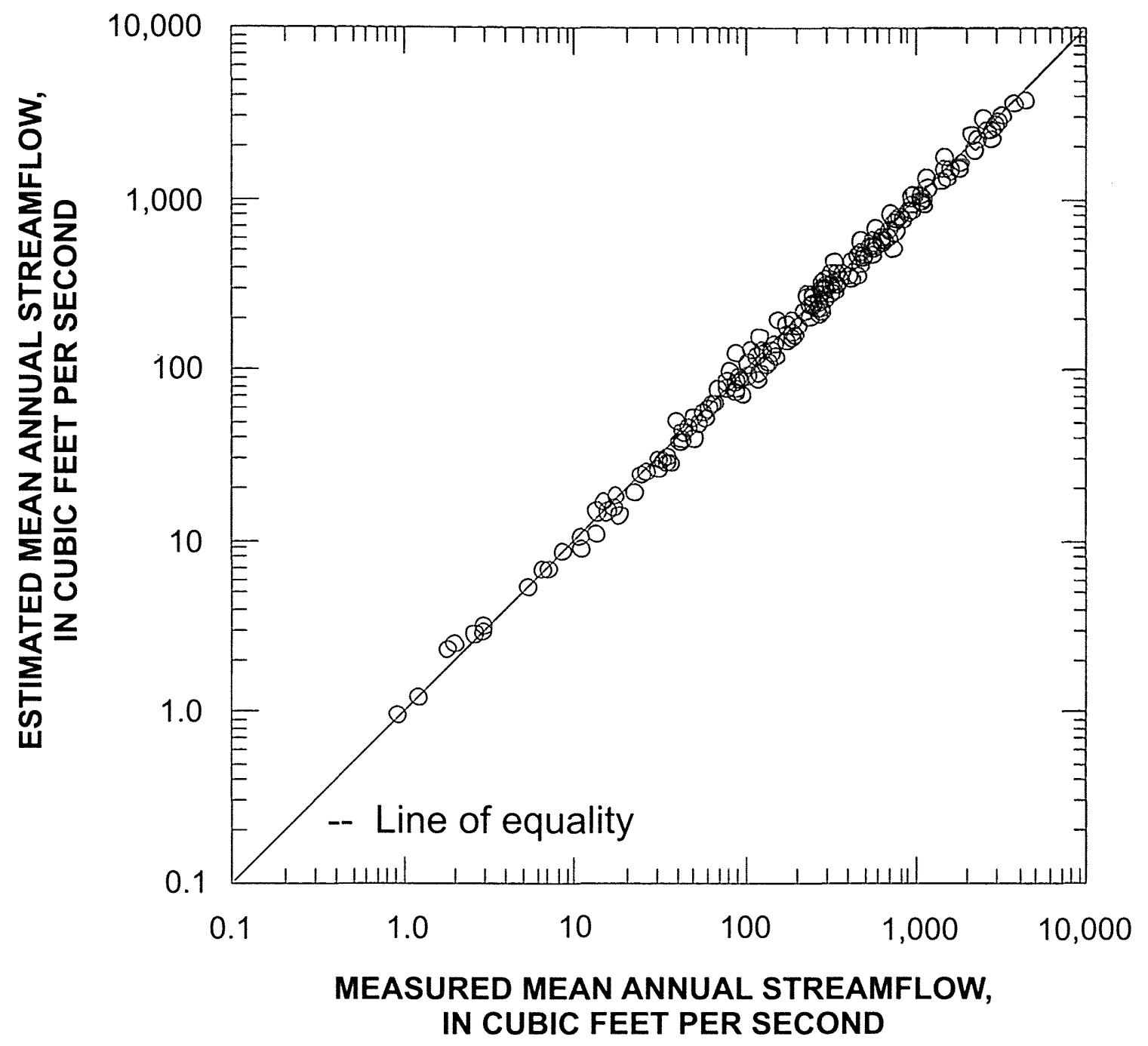

Figure 6. Comparison of measured mean annual streamflow and mean annual streamflow estimated by use of the three-variable regression equation for the 170 continuous-record streamflow-gaging stations in Kentucky and surrounding States used in the regression.

\section{PROCEDURES FOR ESTIMATING MEAN ANNUAL STREAMFLOW AT STREAM SITES IN KENTUCKY}

Procedures for obtaining $Q_{a}$ estimates differ depending on the location of the stream site in relation to streamflow-gaging (gage) locations where $Q_{a}$ has been determined. The appropriate procedures and examples are presented in the following sections.

\section{Stream Sites With Gage Information}

When streamflow-gaging information is available on the reach where an estimate of $Q_{a}$ is desired, the gage information is used where appropriate in making the estimate, as discussed below. 


\section{Sites at Gage Locations}

Estimates of $Q_{a}$ values for 235 continuousrecord streamflow-gaging stations are presented in table 1 . When an estimate of $Q_{a}$ is required at a stream site, refer to table 1 to determine whether values previously have been estimated for the site. At gage locations where the period of record is less than the equivalent years of record reported for the regression models (table 2), except on the Ohio River and where local diversions are significant, an improved estimate of $Q_{a}$ may be obtained from a weighted average of the gaging-station estimate and regression-model estimate. The equivalent years of record can be used to weight the regression-model estimate, and the years of gaged record can be used to weight the gaging-station estimate.

\section{Sites Near Gage Locations}

If information is available for a stream reach where an estimate is desired, but not at the specific location, a weighting procedure can be used (Carpenter, 1983; and G.F. Koltun, U.S. Geological Survey, written commun., 2001). The drainage area of the ungaged site should differ by no more than 50 percent from that of the gaged site (ranging from 50 to 150 percent of the drainage area of the gaged site) to minimize the potential for hydrologic dissimilarity between the sites.

A weighted estimate of $Q_{a}$ can be computed as

$$
Q_{a_{u w}}=Q_{a_{u r}}\left[R-\left(\frac{2(|\Delta A|)(R-1)}{A_{g}}\right)\right]
$$

where $\mathrm{R}=Q_{a_{g m}} / Q_{a_{g r}}$

and $Q_{a_{u w}}$ is the weighted mean annual flow, $Q_{a}$, for the ungaged site;

$Q_{a_{u r}}$ is the regression estimate of the $Q_{a}$ for the ungaged site;
$Q_{a_{g m}}$ is the $Q_{a}$ determined for the gaged site from measured streamflow data;

$Q_{a_{g r}}$ is the regression estimate of the $Q_{a}$ for the gaged site;

$|\Delta A| \quad$ is the absolute value of the difference between the drainage areas of the gaged site and the ungaged site; and

$A_{g} \quad$ is the drainage area of the gaged site.

As the difference in drainage area between the gaged and ungaged site approaches 50 percent, the value of the weighting factor in brackets in equation 9 approaches 1 and no longer has an effect on the regression estimate at the ungaged site.

\section{Sites Between Gage Locations}

If a $Q_{a}$ estimate is desired between two gage locations on the same stream, the value can be estimated by linear interpolation by use of the $Q_{a}$ values and corresponding drainage areas at the two gaged sites.

\section{Stream Sites With No Gage Information}

If no streamflow information is available at a stream site, or at a nearby stream site on the same stream reach so that the estimating methods in the previous section cannot be used, then the regional regression models (table 2) can be used directly to estimate $Q_{a}$.

Total drainage area of the site of interest should be determined from USGS 7.5-minute topographic maps or from other maps or GIS coverages of equivalent or improved accuracy. The drainage areas for many locations along streams in Kentucky are listed in Bower and Jackson (1981). 


\section{EXAMPLE APPLICATIONS OF ESTIMATING EQUATIONS}

The estimating equations presented in this report can be applied to rural, ungaged streams with flows not appreciably affected by local diversions by (1) determining the basin characteristics required for the appropriate equation, (2) checking to ensure that the basin characteristics fall within the range of characteristics values used to develop the equation, and (3) use of the measured basin characteristics values with the appropriate equation to compute the estimate.

For example, assume that an estimate of $Q_{a}$ is needed for an ungaged rural stream site with a drainage area of $80 \mathrm{mi}^{2}$, at a latitude of $37.525^{\circ}$, and a mean basin elevation of $900 \mathrm{ft}$ above sea level. A comparison of basin characteristics with those listed in table 2 indicates that the characteristics for this basin are within the range of characteristics of gaging stations used to develop the estimating equations. Estimates of $Q_{a}$ are computed as

$$
Q_{a}=1.39 A^{1.00}\left(L_{a} t_{g}-36\right)^{-0.15} E^{0.12} .
$$

Substituting the measured basin characteristics into the above equation yields

$$
\begin{gathered}
Q_{a}=1.39(80)^{1.00}(37.525-36)^{-0.15}(0.900)^{0.12} \\
=103 \mathrm{ft}^{3} / \mathrm{s}
\end{gathered}
$$

If it is desired to quickly obtain an approximate estimate by use of the drainage-areaonly equation, then the first equation in table 2 is applied:

$$
Q_{a}=1.38 A^{1.01} .
$$

Substituting the measured basin characteristics into the above equation yields

$$
Q_{a}=1.38(80)^{1.01}=115 \mathrm{ft}^{3} / \mathrm{s} .
$$

In situations where an estimate of $Q_{a}$ is needed at a stream site on a reach near a gage location and the drainage area at the point of interest is between 50 and 150 percent of the drainage area of the gaged site, then equation 9 can be applied to obtain a $Q_{a}$ estimate weighted by use of gagingstation information as shown in the following example.

Assume there is a streamflow-gaging station located downstream on the same stream reach used in the previous example with a drainage area of $85.9 \mathrm{mi}^{2}$, a latitude of $37.704^{\circ}$, and a mean basin elevation of $866 \mathrm{ft}$ above sea level. The $Q_{a}$ at the gaged site as computed from the long-term streamflow data is $104 \mathrm{ft}^{3} / \mathrm{s}$. The regression estimate of $Q_{a}$ at the gaged site is

$$
\begin{gathered}
Q_{a}=1.39(85.9)^{1.00}(37.704-36)^{-0.15}(0.866)^{0.12} \\
=108 \mathrm{ft}^{3} / \mathrm{s} .
\end{gathered}
$$

The coefficient $R$ is determined as

$$
R=Q_{a_{g m}} / Q_{a_{g r}}=\frac{104}{108}=0.963 .
$$

The gage-weighted $Q_{a}$ estimate for the ungaged site is computed as

$$
Q_{a_{u w}}=Q_{a_{u r}}\left[R-\left(\frac{2(|\Delta A|)(R-1)}{A_{g}}\right)\right]
$$

$$
\begin{gathered}
Q_{a_{u w}}= \\
103\left[0.963-\left(\frac{2(|85.9-80.01|)(0.963-1)}{85.9}\right)\right] \\
Q_{a_{u w}}=99.7 \mathrm{ft}^{3} / \mathrm{s} .
\end{gathered}
$$

This adjusted $Q_{a}$ estimate for the ungaged upstream site, $99.7 \mathrm{ft}^{3} / \mathrm{s}$, is 96 percent of the measured long-term $Q_{a}(104)$ at the gaged site. This result is consistent with the ratio of the drainage areas of these two sites, 0.93 , and is reasonable. 


\section{SUMMARY}

Mean annual streamflow data are needed by water-resource managers and engineers for design of structures in streams and rivers. Techniques for estimating streamflow characteristics at ungaged sites are part of this need; therefore, the U.S. Geological Survey, in cooperation with the Kentucky Transportation Cabinet-Department of Highways, began a study in 1999 to compile available continuous-record streamflow-gaging data, compute mean annual flow at streamflowgaging stations, and develop equations for estimating mean annual streamflow at ungaged rural stream sites.

The values of mean annual streamflow, $Q_{a}$, were determined at selected streamflow-gaging stations in Kentucky and surrounding States. Streamflow data for the available period of record through the 1999 water year at 235 continuousrecord streamflow-gaging stations with at least 5 years of record were used in the analysis. Record extension at selected stations was accomplished by use of the MOVE.1 technique to reduce timesampling error and, thus, improve estimates of longterm $Q_{a}$ values.

Techniques to estimate $Q_{a}$ at ungaged stream sites in Kentucky were developed. A multiplelinear-regression analysis was used to relate $Q_{a}$ values to drainage-basin characteristics. One-, two-, and three-variable regression equations that included total drainage area, streamflow-gaging station latitude minus 36 degrees, and mean basin elevation as explanatory variables were developed by use of generalized-least-squares regression, which compensated for differences in the variability and reliability of, and correlation among, the $Q_{a}$ estimates at the 170 gaging stations with 10 or more years of record included in the regression analysis. The three-variable regression equation has an approximate average standard error of prediction of 13.7 percent. The one- and two-variable equations exhibit geographical biases, and the indicated standard errors of prediction may estimate poorly the true prediction errors, depending on the location in the State. The one- and two-variable models are suitable for initial approximate $Q_{a}$ estimates; however, the three-variable equation should be used whenever possible for estimating mean annual streamflow of rural streams in Kentucky. Estimating equations can be applied by (1) determining the basin characteristics required for the appropriate equation, (2) checking to ensure that the basin characteristics are within the range of values used to develop the equation, and (3) substituting the basincharacteristic values for the variables in the estimating equations as described in the example applications presented.

\section{REFERENCES CITED}

Allen, D.M., 1971, Mean square error of prediction as a criterion for selecting prediction variables:

Technometrics, v. 13, p. 469-475.

1974, The relationship between variable selection and data augmentation and a method for prediction: Technometrics, v. 16, no. 1, p. 125-127.

Bartholoma, S.D., comp., 1997, User's manual for the National Water Information System of the U.S. Geological Survey, chap. 3, Automated Data Processing System: U.S. Geological Survey OpenFile Report 97-635, 219 p.

Beaber, H.C., 1970, A proposed streamflow data program for Kentucky: U.S. Geological Survey Open-File Report (unnumbered), $48 \mathrm{p}$.

Bingham, R.H., 1982, Low-flow characteristics of Alabama streams: U.S. Geological Survey WaterSupply Paper 2083, 27 p.

Bower, D.E., and Jackson, W.H., 1981, Drainage areas of streams at selected locations in Kentucky: U.S. Geological Survey Open-File Report 81-61, $118 \mathrm{p}$.

Carpenter, D.H., 1983, Characteristics of streamflow in Maryland: Maryland Geological Survey Report of Investigations No. 35, 237 p.

Choquette, A.F., 1988, Regionalization of peak discharges for streams in Kentucky: U.S. Geological Survey Water-Resources Investigations Report 87-4209, $105 \mathrm{p}$.

Conner, Glen, 1982, Monthly, seasonal, and annual precipitation in Kentucky 1951-1980: Bowling Green, Ky., Western Kentucky University, Kentucky Climate Center Publication Number 25, $30 \mathrm{p}$.

Crawford, N., and Webster, J., 1986, Karst hazard assessment of Kentucky-Sinkhole flooding and collapse: Bowling Green, Ky., Western Kentucky University, Center for Cave and Karst Studies, prepared for the U.S. Environmental Protection Agency, Region IV, Atlanta, Ga., scale 1:1,000,000, 1 sheet. 
Dempster, G.R., Jr., 1990, National water information user's manual, v. 2, chap. 3, Automated data processing system: U.S. Geological Survey OpenFile Report 90-116, 321 p.

Hardison, C.H., 1971, Prediction error of regression estimates of streamflow characteristics at ungaged sites: U.S. Geological Survey Professional Paper 750-C, 9 p.

Hershfield, D.M., 1961, Rainfall frequency atlas of the United States: U.S. Department of Commerce, Technical Paper No. 40, 115 p.

Hirsch, R.M., 1982, A comparison of four streamflow record extension techniques: Water Resources Research, v. 18 , no. 4, p. 1,082-1,088.

Kentucky Department for Natural Resources and Environmental Protection, 1979, Rainfall frequency values for Kentucky: Frankfort, Ky., Bureau of Environmental Protection, Division of Water, Engineering Memorandum No. 2, 37 p.

Kentucky Geological Survey, 1980, Physiographic diagram of Kentucky: Lexington, Ky., University of Kentucky, 1 map, scale not specified.

Lane, E.W., and Lei, Kai, 1950, Streamflow variability, in Proceedings of the American Society of Civil Engineers, Transactions, v. 115, p. 1,084-1,134.

Lins, H.F., and Slack, J.R., 1999, Streamflow trends in the United States: Geophysical Research Letters, v. 26, no. 2, p. 227-230.

Marquardt, D.W., 1970, Generalized inverses, ridge regression, biased linear estimation, and nonlinear estimation: Technometrics, v. 12, p. 591-612.

Martin, G.R., and Ruhl, K.J., 1993, Regionalization of harmonic-mean streamflows in Kentucky: U.S. Geological Survey Water-Resources Investigations Report 92-4173, 47 p., 1 pl.

Mathsoft, Inc., 1999a, S-Plus 2000, Modern Statistics and Advanced Graphics, Guide to Statistics, Volume 1: Seattle, Wash., Data Analysis Products Division, $638 \mathrm{p}$.

1999b, S-Plus 2000, Modern Statistics and Advanced Graphics, Guide to Statistics, Volume 2: Seattle, Wash., Data Analysis Products Division, $582 \mathrm{p}$.

McGrain, Preston, and Currens, J.C., 1978, Topography of Kentucky: Lexington, Ky., University of Kentucky, Kentucky Geological Survey, ser. X, Special Publication 25, $76 \mathrm{p}$.

McFarland, A.C., 1950, Geology of Kentucky: Lexington, Ky., University of Kentucky, 531 p.

Melcher, N.B., and Ruhl, K.J., 1984, Streamflow and basin characteristics at selected sites in Kentucky: U.S. Geological Survey Open-File Report 84-704, $80 \mathrm{p}$.
Montgomery, D.C., and Peck, E.A., 1982, Introduction to linear regression analysis: New York, Wiley, $504 \mathrm{p}$.

Musgrave, G.W., 1955, How much of the rain enters the soil?: U.S. Department of Agriculture, Yearbook of Agriculture-Water, p. 151-159.

Riggs, H.C., 1964, The base-flow recession curve as an indicator of groundwater: Berkeley, Calif., International Association of Scientific Hydrology Publication 63, p. 352-363.

Ruhl, K.J., and Martin, G.R., 1991, Low-flow characteristics of Kentucky streams: U:S. Geological Survey Water-Resources Investigations Report 91-4097, 50 p.

Searcy, J.K., 1959, Flow-duration curves: U.S. Geological Survey Water-Supply Paper 1542-A, 33 p.

Statistical Analysis System Institute, Inc., 1985, SAS User's Guide-Statistics: Cary, N.C., Statistical Analysis System Institute, Inc., 956 p.

Stedinger, J.R., and Tasker, G.D., 1985, Regional hydrologic regression, 1 . Ordinary, weighted and generalized least squares compared: Water Resources Research, v. 21, no. 9, p. 1,421-1,432.

1986, Correlation to regional hydrologic analysis, 1. Ordinary, weighted and generalized least squares compared: Water Resources Research, v. 22, no. 5, 844 p.

Tasker, G.D., and Stedinger, J.R., 1989, An operational GLS model for hydrologic regression: Journal of Hydrology, v. 111, p. 361-375.

Thomas, D.M., and Benson, M.A., 1970, Generalization of streamflow characteristics from drainage-basin characteristics: U.S. Geological Survey WaterSupply Paper 1975, 55 p.

U.S. Department of Agriculture, 1969, National engineering handbook: Soil Conservation Service, sec. 4, Hydrology, chaps. 9, 10.

1975, General soil map of Kentucky: Soil Conservation Service Map No. 4-R-34874, scale $1: 750,000$.

1984, Predicting soil loss in Kentucky: Lexington, Ky., Soil Conservation Service Technical Paper No. 4, 152 p.

U.S. Geological Survey, 1958a, Compilation of records of surface waters of the United States through 1950, Part 3-A. Ohio River Basin except Cumberland and Tennessee River basins: U.S. Geological Survey Water-Supply Paper 1305, 652 p.

$1958 \mathrm{~b}$, Compilation of records of surface waters of the United States through 1950, Part 3-B. Cumberland and Tennessee River basins: U.S. Geological Survey Water-Supply Paper 1306, $353 \mathrm{p}$. 
$1964 a$, Compilation of records of surface waters of the United States, October 1950 to September 1960, Part 3-A. Ohio River basin except Cumberland and Tennessee River basins: U.S. Geological Survey Water-Supply Paper 1725, 560 p.

1964b, Compilation of records of surface waters of the United States, October 1950 to September 1960, Part 3-B. Cumberland and Tennessee River basins: U.S. Geological Survey Water-Supply Paper 1726, 269 p.

1962-65, Surface water records of Kentucky, 1961-64: U.S. Geological Survey (published annually).

1966-75, Water resources data for Kentucky, 1965-74-part 1. Surface-water records: U.S. Geological Survey Water-Data Reports (published annually).

1976-2000, Water resources data for Kentucky, water years 1975-99: U.S. Geological Survey Water-Data Reports KY-75-1 to KY 99-1 (published annually).

Wetzel, K.L., and Bettandorff, J.M., 1986, Techniques for estimating streamflow characteristics in the Eastern and Interior Coal Provinces of the United States: U.S. Geological Survey Water-Supply Paper 2276, $80 \mathrm{p}$.

\section{GLOSSARY}

\section{COEFFICIENT OF MULTIPLE}

DETERMINATION.-The proportion of the variation in the dependent variable explained by the variables in a fitted regression model. Reported values are adjusted for error degrees of freedom.

LEVEL OF SIGNIFICANCE.-The selected maximum probability of making a Type I error, or rejecting a true null hypothesis. Hypothesis tests were used to determine if statistically significant relations existed between dependent and explanatory variables of regression models.

LOCAL DIVERSION.-A localized transfer of water, such as a water-supply withdrawal or wastewater releases, that artificially increase or decrease streamflow in a reach.

MULTICOLLINEARITY.-The presence of a high correlation (near linear dependencies) between two or more explanatory variables of a regression. Multicollinearity causes instability in the estimates of the least-squares regression coefficients.
MULTIPLE-LINEAR REGRESSION.-A method of regression wherein a linear relation between a dependent variable and more than one explanatory variable is defined.

\section{ORDINARY-LEAST-SQUARES REGRESSION.-A} method of fitting a regression model in which the sum of squared residuals (see Residual) is minimized.

\section{PREDICTION SUM OF SQUARES (PRESS)}

STATISTIC.-A measure of model-prediction error useful in regression-model selection. It is computed by summing the square of the prediction residuals resulting from the series of predictions of each observation by regressions defined using all other observations. Thus, each observation is in turn excluded from the regression data set and is not used in prediction of itself. This process simulates prediction using new data and is a form of data splitting useful for model validation (Allen 1971, 1974; and Montgomery and Peck, 1982).

REGULATED STREAMFLOW.-Streamflow controlled by upstream hydraulic structures such as dams.

RESIDUAL.-The difference between values of mean annual streamflow computed by use of streamflowgaging data and values estimated by use of a regression model.

STANDARD ERROR OF ESTIMATE.-A measure of model-fitting error; it is the standard deviation of the residuals of a regression adjusted for error degrees of freedom. Percentage values in this report were estimated by use of model root-mean-square error, or the square root of the sum of the squares of the residuals divided by the error degrees of freedom- $n-k-1$, where $n$ is the number of observations and $k$ is the number of explanatory variables in the regression-(Statistical Analysis System Institute, Inc., 1985) and information from Hardison (1971).

STANDARD ERROR OF PREDICTION.-A measure of model-prediction error; it was estimated as the square root of the PRESS divided by the degrees of freedom for error (Statistical Analysis System Institute, Inc., 1985; Montgomery and Peck, 1982; and Choquette, 1988). (See Prediction Sum of Squares (PRESS) Statistic.) 
STREAMFLOW.-Discharge, measured as the volume of water that passes a given point within a given period of time (cubic feet per second), that occurs in a natural channel whether or not it is affected by diversion or regulation.

STREAMFLOW-GAGING STATION.-An installation that provides systematic observations of stage from which streamflow is computed.
VARIANCE INFLATION FACTOR (VIF).-An indicator of multicollinearity; it is a measure of the combined effect of the dependencies among explanatory variables on the variance of each term in a regression model (Marquardt, 1970; and Montgomery and Peck, 1982).

WATER YEAR.-The 12-month period from October 1 through September 30. The water year is designated by the calendar year in which it ends. 
Table 1. Continuous-record streamflow-gaging stations used in the study, selected basin characteristics, periods of record used in the analysis, corresponding mean annual flows, and selected reservoirs and diversions in the basin for Kentucky and surrounding States

[ $\mathrm{mi}^{2}$, square miles; $\mathrm{ft}^{3} / \mathrm{s}$, cubic feet per second; $\mathrm{ft}^{3} / \mathrm{s} / \mathrm{mi}^{2}$, cubic feet per second per square mile; --, not applicable; LD, local diversion; all stations are in Kentucky unless otherwise noted]

\begin{tabular}{|c|c|c|c|c|c|c|c|c|c|c|}
\hline $\begin{array}{l}\text { Station } \\
\text { number }\end{array}$ & Station name & $\begin{array}{l}\text { Total } \\
\text { drainage } \\
\text { area } \\
\left(\mathrm{mi}^{2}\right)\end{array}$ & $\begin{array}{c}\text { Gage } \\
\text { latitude } \\
\text { (decimal } \\
\text { degrees) }\end{array}$ & $\begin{array}{c}\text { Gage } \\
\text { longitude } \\
\text { (decimal } \\
\text { degrees) }\end{array}$ & $\begin{array}{c}\text { Mean } \\
\text { basin } \\
\text { elevation } \\
\text { (feet } \\
\text { above } \\
\text { sea level) }\end{array}$ & $\begin{array}{l}\text { Period of } \\
\text { record used } \\
\text { in the } \\
\text { analysis } \\
\text { (water } \\
\text { years }{ }^{1} \text { ) }\end{array}$ & $\begin{array}{c}\text { Number } \\
\text { of } \\
\text { years }\end{array}$ & $\begin{array}{c}\text { Mean } \\
\text { annual } \\
\text { flow } \\
\left(\mathrm{ft}^{3} / \mathrm{s}\right)\end{array}$ & $\begin{array}{c}\text { Standardized } \\
\text { mean annual } \\
\text { flow } \\
\left(\mathrm{ft}^{3} / \mathrm{s} / \mathrm{mi}^{2}\right)\end{array}$ & $\begin{array}{l}\text { Selected reservoirs } \\
\text { in basin and } \\
\text { start date or type of } \\
\text { local diversion and } \\
\text { location }\end{array}$ \\
\hline 03202400 & $\begin{array}{l}\text { Guyandotte River near Baileysville, } \\
\text { West Virginia }\end{array}$ & 306 & 37.600 & 81.650 & 2,106 & $1969-98$ & 30 & 424 & 1.39 & - \\
\hline 03203000 & $\begin{array}{l}\text { Guyandotte River at Man, } \\
\text { West Virginia }\end{array}$ & 758 & 37.740 & 81.880 & 1,878 & $1930-62$ & 33 & 984 & 1.30 & -- \\
\hline 03203600 & $\begin{array}{l}\text { Guyandotte River at Logan, } \\
\text { West Virginia }\end{array}$ & 833 & 37.840 & 82.000 & 1,827 & $1963-98$ & 36 & 1,170 & 1.40 & -- \\
\hline 03204500 & Mud River near Milton, West Virginia & 256 & 38.390 & 82.110 & 909 & $1939-80$ & 42 & 290 & 1.13 & -- \\
\hline 03206600 & $\begin{array}{l}\text { East Fork Twelvepole Creek near } \\
\text { Dunlow, West Virginia }\end{array}$ & 38.5 & 38.020 & 82.300 & 1,081 & $1965-98$ & 34 & 53.5 & 1.39 & -- \\
\hline 03207000 & $\begin{array}{l}\text { Twelvepole Creek at Wayne, } \\
\text { West Virginia }\end{array}$ & 291 & 38.220 & 82.450 & 986 & $\begin{array}{l}1916-17 \\
1928-31 \\
1947-54 \\
1956-66\end{array}$ & 25 & 320 & 1.10 & -- \\
\hline 03207020 & $\begin{array}{l}\text { Twelvepole Creek below Wayne, } \\
\text { West Virginia }\end{array}$ & 300 & 38.250 & 82.430 & 980 & $\begin{array}{l}1916-17 \\
1928-31 \\
1947-54 \\
1956-82\end{array}$ & 40 & 349 & 1.16 & -- \\
\hline 03207500 & Levisa Fork near Grundy, Virginia & 235 & 37.300 & 82.130 & 2,036 & $\begin{array}{l}1942-74 \\
1986-87\end{array}$ & 34 & 290 & 1.23 & -- \\
\hline 03207962 & Dicks Fork at Phyllis & .82 & 37.449 & 82.338 & 1,500 & $1976-84$ & 9 & .94 & 1.15 & -- \\
\hline 03207965 & Grapevine Creek near Phyllis & 6.20 & 37.432 & 82.354 & 1,429 & $\begin{array}{l}1974-82 \\
1990-92 \\
1995-99\end{array}$ & 17 & 8.46 & 1.36 & - \\
\hline 03208000 & $\begin{array}{l}\text { Levisa Fork below Fishtrap Dam, } \\
\text { near Millard }\end{array}$ & 392 & 37.416 & 82.421 & 1,810 & 1939-92 & 54 & 475 & 1.21 & Fishtrap Lake, 10/68 \\
\hline 03208500 & Russel Fork at Haysi, Virginia & 286 & 37.210 & 82.300 & 1,996 & $1927-99$ & 73 & 336 & 1.18 & - \\
\hline 03208950 & $\begin{array}{l}\text { Cranes Nest River near Clintwood, } \\
\text { Virginia }\end{array}$ & 66.5 & 37.120 & 82.440 & 2,074 & $1964-99$ & 36 & 79.9 & 1.20 & -- \\
\hline 03209000 & $\begin{array}{l}\text { Pound River below Flannagan Dam } \\
\text { near Haysi, Virginia }\end{array}$ & 221 & 37.229 & 82.343 & 1,965 & $1927-99$ & 72 & 277 & 1.26 & Flannagan Lake, 12/63 \\
\hline 03209300 & Russell Fork at Elkhorn City & 554 & 37.304 & 82.343 & 1,950 & $1961-92$ & 32 & 708 & 1.28 & $\begin{array}{l}\text { Flannagan Lake, 12/63; } \\
\text { North Fork Pound } \\
\text { Lake, } 08 / 66\end{array}$ \\
\hline
\end{tabular}


Table 1. Continuous-record streamflow-gaging stations used in the study, selected basin characteristics, periods of record used in the analysis, corresponding mean annual flows, and selected reservoirs and diversions in the basin for Kentucky and surrounding States-Continued

$\left[\mathrm{mi}^{2}\right.$, square miles; $\mathrm{ft}^{3} / \mathrm{s}$, cubic feet per second; $\mathrm{ft}^{3} / \mathrm{s} / \mathrm{mi}^{2}$, cubic feet per second per square mile; --, not applicable; LD, local diversion; all stations are in Kentucky unless otherwise noted]

\begin{tabular}{|c|c|c|c|c|c|c|c|c|c|c|}
\hline $\begin{array}{l}\text { Station } \\
\text { number }\end{array}$ & Station name & $\begin{array}{l}\text { Total } \\
\text { drainage } \\
\text { area } \\
\left(\mathrm{mi}^{2}\right)\end{array}$ & $\begin{array}{c}\text { Gage } \\
\text { latitude } \\
\text { (decimal } \\
\text { degrees) }\end{array}$ & $\begin{array}{c}\text { Gage } \\
\text { longitude } \\
\text { (decimal } \\
\text { degrees) }\end{array}$ & $\begin{array}{c}\text { Mean } \\
\text { basin } \\
\text { elevation } \\
\text { (feet } \\
\text { above } \\
\text { sea level) }\end{array}$ & $\begin{array}{l}\text { Period of } \\
\text { record used } \\
\text { in the } \\
\text { analysis } \\
\text { (water } \\
\text { years }{ }^{1} \text { ) }\end{array}$ & $\begin{array}{c}\text { Number } \\
\text { of } \\
\text { years }\end{array}$ & $\begin{array}{c}\text { Mean } \\
\text { annual } \\
\text { flow } \\
\left(\mathrm{ft}^{3} / \mathrm{s}\right)\end{array}$ & $\begin{array}{c}\text { Standardized } \\
\text { mean annual } \\
\text { flow } \\
\left(\mathrm{ft}^{3} / \mathrm{s} / \mathrm{mi}^{2}\right)\end{array}$ & $\begin{array}{l}\text { Selected reservoirs } \\
\text { in basin and } \\
\text { start date or type of } \\
\text { local diversion and } \\
\text { location }\end{array}$ \\
\hline 03209500 & Levisa Fork at Pikeville & 1,232 & 37.476 & 82.518 & 1,789 & $1938-99$ & 62 & 1,470 & 1.19 & $\begin{array}{l}\text { Flannagan Lake, } 12 / 63 ; \\
\text { North Fork Pound } \\
\text { Lake, 08/66 } \\
\text { Fishtrap Lake, 10/68 }\end{array}$ \\
\hline 03209800 & Levisa Fork at Prestonsburg & 1,702 & 37.671 & 82.777 & 1,628 & 1964-81 & 18 & 2,130 & 1.25 & $\begin{array}{l}\text { Flannagan Lake, 12/63; } \\
\text { North Fork Pound } \\
\text { Lake, 08/66 } \\
\text { Fishtrap Lake, 10/68 }\end{array}$ \\
\hline 03210000 & Johns Creek near Meta & 56.3 & 37.567 & 82.458 & 1,384 & $\begin{array}{l}1.942-93 \\
1995-99\end{array}$ & 57 & 68.9 & 1.22 & -- \\
\hline 03211500 & Johns Creek near Van Lear & 206 & 37.744 & 82.724 & 1,154 & $1940-92$ & 53 & 232 & 1.12 & Dewey Lake, 05/50 \\
\hline 03212000 & Paint Creek at Staffordsville & 103 & 37.835 & 82.871 & 965 & $1951-75$ & 25 & 128 & 1.25 & - \\
\hline 03212500 & Levisa Fork at Paintsville & 2,144 & 37.815 & 82.792 & 1,485 & $\begin{array}{l}1916 \\
1929-99\end{array}$ & 72 & 2,480 & 1.16 & $\begin{array}{l}\text { Dewey Lake, } 05 / 50 ; \\
\text { Flannagan Lake, } 12 / 63 \text {; } \\
\text { North Fork Pound } \\
\quad \text { Lake, } 08 / 66 \\
\text { Fishtrap Lake, } 10 / 68 \\
\text { Paintsville Lake, } 09 / 83\end{array}$ \\
\hline 03213700 & $\begin{array}{l}\text { Tug Fork at Williamson, } \\
\text { West Virginia }\end{array}$ & 936 & 37.673 & 82.280 & 1,731 & $1968-98$ & 31 & 1,140 & 1.22 & - \\
\hline 03215000 & Big Sandy River at Louisa & 3,897 & 38.171 & 82.635 & - & $\begin{array}{l}1940-47 \\
1949-76\end{array}$ & 36 & 4,440 & 1.14 & $\begin{array}{l}\text { Dewey Lake, } 05 / 50 ; \\
\text { Flannagan Lake, } 12 / 63 ; \\
\text { North Fork Pound } \\
\quad \text { Lake, } 08 / 66 \\
\text { Fishtrap Lake, } 10 / 68 \\
\text { Paintsville Lake, } 09 / 83\end{array}$ \\
\hline 03215500 & Blaine Creek at Yatesville & 217 & 38.144 & 82.685 & 862 & $\begin{array}{l}1916-18 \\
1939-75\end{array}$ & 40 & 247 & 1.14 & - \\
\hline 03216000 & Ohio River at Ashland & 60,750 & 38.481 & 82.637 & -- & $1940-52$ & 13 & ${ }^{2} 84,000$ & 1.38 & Various \\
\hline 03216350 & $\begin{array}{l}\text { Little Sandy River below Grayson } \\
\text { Dam near Leon }\end{array}$ & 196 & 38.254 & 82.991 & 912 & $1967-92$ & 26 & 241 & 1.23 & Grayson Lake, 03/68 \\
\hline 03216400 & Little Sandy River at Leon & 255 & 38.286 & 82.977 & 905 & $1962-80$ & 19 & 314 & 1.23 & Grayṣon Lake, 03/68 \\
\hline 03216500 & Little Sandy River at Grayson & 400 & 38.330 & 82.939 & 875 & $1939-99$ & 61 & 479 & 1.20 & Grayson Lake, 03/68 \\
\hline 03216540 & $\begin{array}{l}\text { East Fork Little Sandy River near } \\
\text { Fallsburg }\end{array}$ & 12.2 & 38.234 & 82.709 & 855 & $1973-91$ & 19 & 15.6 & 1.28 & -- \\
\hline
\end{tabular}



Table 1. Continuous-record streamflow-gaging stations used in the study, selected basin characteristics, periods of record used in the analysis, corresponding mean annual flows, and selected reservoirs and diversions in the basin for Kentucky and surrounding States-Continued

$\left[\mathrm{mi}^{2}\right.$, square miles; $\mathrm{ft}^{3} / \mathrm{s}$, cubic feet per second; $\mathrm{ft}^{3} / \mathrm{s} / \mathrm{mi}^{2}$, cubic feet per second per square mile; --, not applicable; LD, local diversion; all stations are in Kentucky unless otherwise noted]

\begin{tabular}{|c|c|c|c|c|c|c|c|c|c|c|}
\hline $\begin{array}{l}\text { Station } \\
\text { number }\end{array}$ & Station name & $\begin{array}{l}\text { Total } \\
\text { drainage } \\
\text { area } \\
\left(\mathrm{mi}^{2}\right)\end{array}$ & $\begin{array}{c}\text { Gage } \\
\text { latitude } \\
\text { (decimal } \\
\text { degrees) }\end{array}$ & $\begin{array}{c}\text { Gage } \\
\text { longitude } \\
\text { (decimal } \\
\text { degrees) }\end{array}$ & $\begin{array}{c}\text { Mean } \\
\text { basin } \\
\text { elevation } \\
\text { (feet } \\
\text { above } \\
\text { sea level) }\end{array}$ & $\begin{array}{l}\text { Period of } \\
\text { record used } \\
\text { in the } \\
\text { analysis } \\
\text { (water } \\
\text { years }{ }^{1} \text { ) }\end{array}$ & $\begin{array}{c}\text { Number } \\
\text { of } \\
\text { years }\end{array}$ & $\begin{array}{c}\text { Mean } \\
\text { annual } \\
\text { flow } \\
\left(\mathrm{ft}^{3} / \mathrm{s}\right)\end{array}$ & $\begin{array}{c}\text { Standardized } \\
\text { mean annual } \\
\text { flow } \\
\left(\mathrm{ft}^{3} / \mathrm{s} / \mathrm{mi}^{2}\right)\end{array}$ & $\begin{array}{c}\text { Selected reservoirs } \\
\text { in basin and } \\
\text { start date or type of } \\
\text { local diversion and } \\
\text { location }\end{array}$ \\
\hline 03251500 & Licking River at McKinneysburg & 2,326 & 38.598 & 84.267 & 921 & $\begin{array}{l}1925 \\
1939-94\end{array}$ & 57 & 3,030 & 1.30 & Cave Run Lake, $12 / 73$ \\
\hline 03252000 & Stoner Creek at Paris & 239 & 38.229 & 84.256 & 929 & $1954-91$ & 38 & 294 & 1.23 & $\begin{array}{l}\text { LD _ waste disposal, } \\
\text { Paris (minor) }\end{array}$ \\
\hline 03252300 & Hinkston Creek at Carlisle & 154 & 38.242 & 84.053 & 936 & $1992-99$ & 8 & 208 & 1.35 & -- \\
\hline 03252500 & $\begin{array}{l}\text { South Fork Licking River at } \\
\text { Cynthiana }\end{array}$ & 621 & 38.391 & 84.303 & 907 & $1939-94$ & 56 & 766 & 1.23 & $\begin{array}{l}\text { LD - water supply, } \\
\text { Cynthiana (minor) }\end{array}$ \\
\hline 03253500 & Licking River at Catawba & 3,300 & 38.710 & 84.311 & - & $\begin{array}{l}\text { 1916-17, } \\
1929-99\end{array}$ & 73 & 4,140 & 1.26 & Cave Run Lake, 12/73 \\
\hline 03254400 & North Fork Grassy Creek near Piner & 13.6 & 38.792 & 84.514 & 816 & $1968-83$ & 16 & 17.0 & 1.25 & - \\
\hline 03255000 & Ohio River at Cincinnati, Ohio & 76,580 & 39.094 & 84.511 & -- & $1940-62$ & 23 & ${ }^{2} 99,700$ & 1.30 & Various \\
\hline 03277200 & Ohio River at Markland Dam & 83,170 & 38.775 & 84.964 & -- & $1971-99$ & 29 & ${ }^{2} 108,000$ & 1.30 & Various \\
\hline 03277400 & Leatherwood Creek at Daisy & 40.9 & 37.113 & 83.092 & 1,668 & $\begin{array}{l}1965-74 \\
1992-98\end{array}$ & 17 & 60.4 & 1.48 & -- \\
\hline 03277450 & Carr Fork near Sassafras & 60.6 & 37.231 & 83.036 & 1,439 & $1964-94$ & 31 & 77.6 & 1.28 & Carr Fork Lake, $01 / 76$ \\
\hline 03277500 & North Fork Kentucky River at Hazard & 466 & 37.247 & 83.182 & 1,544 & $1941-93$ & 53 & 576 & 1.24 & Carr Fork Lake, $01 / 76$ \\
\hline 03278000 & Bear Branch near Noble & 2.21 & 37.451 & 83.195 & 1,167 & $1956-73$ & 18 & 2.88 & 1.30 & -- \\
\hline 03278500 & Troublesome Creek at Noble & 177 & 37.443 & 83.218 & 1,273 & $1951-81$ & 31 & 251 & 1.42 & -- \\
\hline 03280000 & $\begin{array}{l}\text { North Fork Kentucky River at } \\
\text { Jackson }\end{array}$ & 1,101 & 37.551 & 83.385 & 1,333 & $\begin{array}{l}\text { 1929-31, } \\
1938-99\end{array}$ & 65 & 1,460 & 1.32 & Carr Fork Lake, $01 / 76$ \\
\hline 03280600 & $\begin{array}{l}\text { Middle Fork Kentucky River near } \\
\text { Hyden }\end{array}$ & 202 & 37.137 & 83.371 & 1,686 & $1958-92$ & 35 & 296 & 1.47 & $\begin{array}{l}\text { LD - water supply, } \\
\text { Hyden (minor) }\end{array}$ \\
\hline 03280700 & Cutshin Creek at Wooton & 61.3 & 37.165 & 83.308 & 1,530 & $1958-99$ & 42 & 93.6 & 1.53 & - \\
\hline 03280900 & $\begin{array}{l}\text { Middle Fork Kentucky River at } \\
\text { Buckhorn }\end{array}$ & 420 & 37.346 & 83.469 & 1,498 & $1957-75$ & 19 & 632 & 1.50 & Buckhorn Lake, 12/60 \\
\hline 03281000 & $\begin{array}{l}\text { Middle Fork Kentucky River at } \\
\text { Tallega }\end{array}$ & 537 & 37.555 & 83.594 & 1,382 & $\begin{array}{l}1931 \\
1940-99\end{array}$ & 61 & 751 & 1.40 & Buckhorn Lake, $12 / 60$ \\
\hline 03281040 & Red Bird River near Big Creek & 155 & 37.179 & 83.593 & 1,407 & 1973-99 & 27 & 280 & 1.81 & - \\
\hline 03281100 & Goose Creek at Manchester & 163 & 37.152 & 83.760 & 1,225 & $1965-99$ & 35 & 266 & 1.63 & - \\
\hline 03281500 & $\begin{array}{l}\text { South Fork Kentucky River at } \\
\text { Booneville }\end{array}$ & 722 & 37.479 & 83.677 & 1,188 & $\begin{array}{l}1926-31 \\
1940-99\end{array}$ & 66 & 1,060 & 1.47 & -. \\
\hline
\end{tabular}


\% Table 1. Continuous-record streamflow-gaging stations used in the study, selected basin characteristics, periods of record used in the analysis, corresponding mean annual flows, and selected reservoirs and diversions in the basin for Kentucky and surrounding States-Continued

$\left[\mathrm{mi}^{2}\right.$, square miles; $\mathrm{ft}^{3} / \mathrm{s}$, cubic feet per second; $\mathrm{ft}^{3} / \mathrm{s} / \mathrm{mi}^{2}$, cubic feet per second per square mile; --, not applicable; LD, local diversion; all stations are in Kentucky unless otherwise noted]

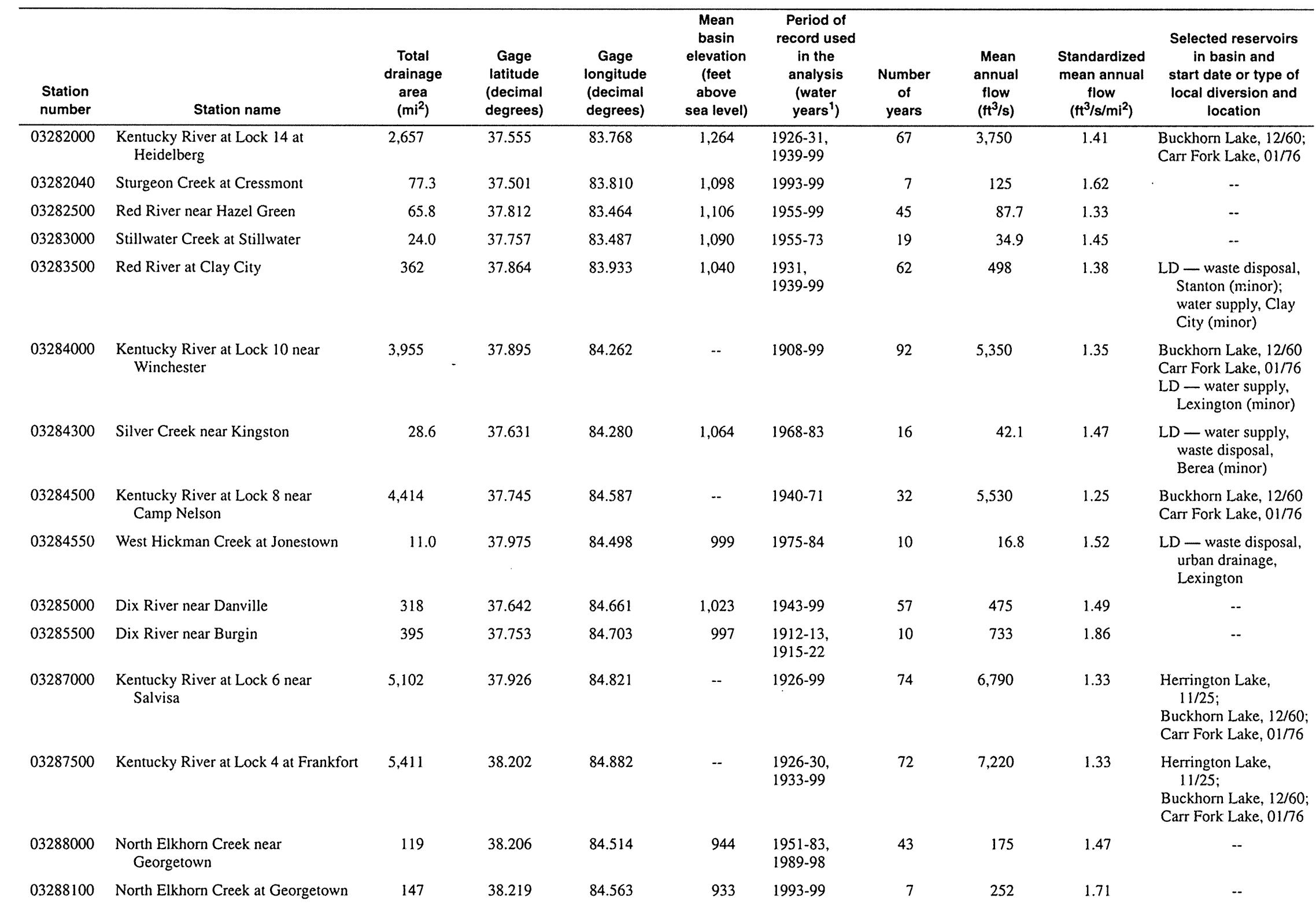


Table 1. Continuous-record streamflow-gaging stations used in the study, selected basin characteristics, periods of record used in the analysis, corresponding mean annual flows, and selected reservoirs and diversions in the basin for Kentucky and surrounding States-Continued

$\left[\mathrm{mi}^{2}\right.$, square miles; $\mathrm{ft}^{3} / \mathrm{s}$, cubic feet per second; $\mathrm{ft}^{3} / \mathrm{s} / \mathrm{mi}^{2}$, cubic feet per second per square mile; --, not applicable; $\mathrm{LD}$, local diversion; all stations are in Kentucky unless otherwise noted]

\begin{tabular}{|c|c|c|c|c|c|c|c|c|c|c|}
\hline $\begin{array}{l}\text { Station } \\
\text { number }\end{array}$ & Station name & $\begin{array}{l}\text { Total } \\
\text { drainage } \\
\text { area } \\
\left(\mathrm{mi}^{2}\right)\end{array}$ & $\begin{array}{c}\text { Gage } \\
\text { latitude } \\
\text { (decimal } \\
\text { degrees) }\end{array}$ & $\begin{array}{c}\text { Gage } \\
\text { longitude } \\
\text { (decimal } \\
\text { degrees) }\end{array}$ & $\begin{array}{c}\text { Mean } \\
\text { basin } \\
\text { elevation } \\
\text { (feet } \\
\text { above } \\
\text { sea level) }\end{array}$ & $\begin{array}{l}\text { Period of } \\
\text { record used } \\
\text { in the } \\
\text { analysis } \\
\text { (water } \\
\text { years }{ }^{1} \text { ) }\end{array}$ & $\begin{array}{c}\text { Number } \\
\text { of } \\
\text { years }\end{array}$ & $\begin{array}{c}\text { Mean } \\
\text { annual } \\
\text { flow } \\
\left(\mathrm{ft}^{3} / \mathrm{s}\right)\end{array}$ & $\begin{array}{c}\text { Standardized } \\
\text { mean annual } \\
\text { flow } \\
\left(\mathrm{ft}^{3} / \mathrm{s} / \mathrm{mi}^{2}\right)\end{array}$ & $\begin{array}{l}\text { Selected reservoirs } \\
\text { in basin and } \\
\text { start date or type of } \\
\text { local diversion and } \\
\text { location }\end{array}$ \\
\hline 03288110 & Royal Spring at Georgetown & - & 38.209 & 84.562 & 890 & $1993-99$ & 7 & 25.2 & -- & $\begin{array}{l}\text { LD - water supply, } \\
\text { Georgetown }\end{array}$ \\
\hline 03288500 & Cave Creek near Fort Spring & 2.53 & 38.021 & 84.594 & 968 & $1953-72$ & 20 & 2.94 & 1.16 & - \\
\hline 03289000 & South Elkhorn Creek at Fort Spring & 24 & 38.043 & 84.626 & 965 & $1950-92$ & 44 & 33.0 & 1.38 & -- \\
\hline 03289300 & South Elkhorn Creek near Midway & 105 & 38.141 & 84.645 & 928 & 1983-99 & 17 & 174 & 1.65 & $\begin{array}{l}\text { LD - waste disposal, } \\
\text { urban drainage, } \\
\text { Lexington }\end{array}$ \\
\hline 03289500 & Elkhorn Creek near Frankfort & 473 & 38.269 & 84.815 & 889 & $\begin{array}{l}1919-20 \\
1941-83 \\
1988-99\end{array}$ & 58 & 644 & 1.36 & $\begin{array}{l}\text { LD - waste disposal, } \\
\text { urban drainage, } \\
\text { Lexington }\end{array}$ \\
\hline 03290000 & Flat Creek near Frankfort & 5.63 & 38.298 & 84.942 & 800 & $1952-71$ & 20 & 6.48 & 1.15 & -. \\
\hline 03290500 & Kentucky River at Lock 2 at Lockport & 6,180 & 38.439 & 84.963 & - & $\begin{array}{l}1927-30 \\
1933-37 \\
1939-99\end{array}$ & 70 & 8,410 & 1.36 & $\begin{array}{l}\text { Herrington Lake, } \\
\text { 11/25; } \\
\text { Buckhorn Lake, 12/60; } \\
\text { Carr Fork Lake, 01/76 }\end{array}$ \\
\hline 03291000 & Eagle Creek at Sadieville & 42.9 & 38.389 & 84.543 & 915 & $1942-75$ & 34 & 58.2 & 1.36 & - \\
\hline 03291500 & Eagle Creek at Glencoe & 437 & 38.705 & 84.824 & 830 & $\begin{array}{l}1916-18 \\
1929-31 \\
1939-77 \\
1990-99\end{array}$ & 55 & 576 & 1.32 & -- \\
\hline 03292460 & Harrods Creek near LaGrange & 24.1 & 38.447 & 85.409 & 796 & $1969-94$ & 26 & 36.9 & 1.53 & - \\
\hline 03292500 & $\begin{array}{l}\text { South Fork Beargrass Creek at } \\
\text { Louisville }\end{array}$ & 17.2 & 38.211 & 85.702 & 543 & $\begin{array}{l}1945-53 \\
1955-62 \\
1971-83 \\
1989-99\end{array}$ & 41 & 22.9 & 1.33 & $\begin{array}{l}\text { LD - waste disposal, } \\
\text { urban drainage, } \\
\text { Louisville }\end{array}$ \\
\hline 03293000 & $\begin{array}{l}\text { Middle Fork Beargrass Creek at } \\
\text { Louisville }\end{array}$ & 18.9 & 38.237 & 85.665 & 621 & $1945-99$ & 55 & 25.4 & 1.34 & $\begin{array}{l}\text { LD - waste disposal, } \\
\text { urban drainage, } \\
\text { Louisville }\end{array}$ \\
\hline 03294000 & Silver Creek near Sellersburg, Indiana & 189 & 38.371 & 85.726 & 597 & $1955-99$ & 45 & 223 & 1.18 & - \\
\hline 03294500 & Ohio River at Louisville & 91,170 & 38.280 & 85.799 & - & $1929-99$ & 71 & 116,000 & 1.27 & Various \\
\hline 03295000 & Salt River near Harrodsburg & 41.4 & 37.757 & 84.873 & 944 & $1953-73$ & 21 & 49.6 & 1.20 & - \\
\hline 03295400 & Salt River at Glensboro & 172 & 38.002 & 85.061 & 850 & $1990-99$ & 10 & 273 & 1.59 & -- \\
\hline 03295500 & Salt River near Van Buren & 196 & 37.968 & 85.134 & 839 & $1939-82$ & 44 & 250 & 1.28 & - \\
\hline
\end{tabular}


$\cong$ Table 1. Continuous-record streamflow-gaging stations used in the study, selected basin characteristics, periods of record used in the analysis, corresponding mean annual flows, and selected reservoirs and diversions in the basin for Kentucky and surrounding States-Continued

$\left[\mathrm{mi}^{2}\right.$, square miles; $\mathrm{ft}^{3} / \mathrm{s}$, cubic feet per second; $\mathrm{ft}^{3} / \mathrm{s} / \mathrm{mi}^{2}$, cubic feet per second per square mile; --, not applicable; LD, local diversion; all stations are in Kentucky unless otherwise noted]

\begin{tabular}{|c|c|c|c|c|c|c|c|c|c|c|}
\hline $\begin{array}{l}\text { Station } \\
\text { number }\end{array}$ & Station name & $\begin{array}{l}\text { Total } \\
\text { drainage } \\
\text { area } \\
\left(\mathrm{mi}^{2}\right)\end{array}$ & $\begin{array}{c}\text { Gage } \\
\text { latitude } \\
\text { (decimal } \\
\text { degrees) }\end{array}$ & $\begin{array}{c}\text { Gage } \\
\text { longitude } \\
\text { (decimal } \\
\text { degrees) }\end{array}$ & $\begin{array}{c}\text { Mean } \\
\text { basin } \\
\text { elevation } \\
\text { (feet } \\
\text { above } \\
\text { sea level) }\end{array}$ & $\begin{array}{l}\text { Period of } \\
\text { record used } \\
\text { in the } \\
\text { analysis } \\
\text { (water } \\
\text { years }{ }^{1} \text { ) }\end{array}$ & $\begin{array}{c}\text { Number } \\
\text { of } \\
\text { years }\end{array}$ & $\begin{array}{c}\text { Mean } \\
\text { annual } \\
\text { flow } \\
\left(\mathrm{ft}^{3} / \mathrm{s}\right)\end{array}$ & $\begin{array}{c}\text { Standardized } \\
\text { mean annual } \\
\text { flow } \\
\left(\mathrm{ft}^{3} / \mathrm{s} / \mathrm{mi}^{2}\right)\end{array}$ & $\begin{array}{c}\text { Selected reservoirs } \\
\text { in basin and } \\
\text { start date or type of } \\
\text { local diversion and } \\
\text { location }\end{array}$ \\
\hline 03295890 & Brashears Creek at Taylorsville & 259 & 38.037 & 85.341 & 772 & $1982-99$ & 18 & 342 & 1.32 & - \\
\hline 03296000 & $\begin{array}{l}\text { Plum Creek Subwatershed number } 4 \\
\text { near Simpsonville }\end{array}$ & 1.55 & 38.174 & 85.368 & 765 & $1956-64$ & 9 & 1.68 & 1.08 & -- \\
\hline 03296500 & Plum Creek near Wilsonville & 19.1 & 38.106 & 85.437 & 719 & $1955-61$ & 7 & 23.6 & 1.23 & -- \\
\hline 03297000 & Little Plum Creek near Waterford & 5.15 & 38.062 & 85.429 & 679 & $1955-61$ & 7 & 6.97 & 1.35 & - \\
\hline 03297500 & Plum Creek at Waterford & 31.8 & 38.051 & 85.432 & 692 & $1955-74$ & 20 & 41.4 & 1.30 & -- \\
\hline 03297845 & Floyds Fork near Crestwood & 46.7 & 38.300 & 85.427 & 768 & $1980-91$ & 12 & 56.7 & 1.21 & -- \\
\hline 03297900 & Floyds Fork near Pewee Valley & 79.9 & 38.285 & 85.468 & 764 & $1992-99$ & 8 & 113 & 1.41 & - \\
\hline 03298000 & Floyds Fork at Fisherville & 138 & 38.188 & 85.460 & 737 & $1945-99$ & 55 & 182 & 1.32 & $\begin{array}{l}\text { LD - waste disposal, } \\
\text { irrigation water } \\
\text { supply }\end{array}$ \\
\hline 03298500 & Salt River at Shepherdsville & 1,197 & 37.985 & 85.717 & 722 & $1939-99$ & 61 & 1,590 & 1.33 & $\begin{array}{l}\text { Taylorsville Lake, } \\
01 / 83\end{array}$ \\
\hline 03298550 & Long Lick near Clermont & 7.91 & 37.928 & 85.654 & 683 & $1993-99$ & 7 & 11.7 & 1.48 & -- \\
\hline 03299000 & Rolling Fork near Lebanon & 239 & 37.497 & 85.324 & 932 & $1939-92$ & 54 & 349 & 1.46 & -. \\
\hline 03300000 & Beech Fork near Springfield & 85.9 & 37.704 & 85.146 & 866 & $1953-72$ & 20 & 104 & 1.21 & -- \\
\hline 03300400 & Beech Fork at Maud & 436 & 37.833 & 85.296 & 820 & $1973-99$ & 27 & 638 & 1.46 & -- \\
\hline 03301000 & Beech Fork at Bardstown & 669 & 37.797 & 85.481 & 786 & $\begin{array}{l}1941-74 \\
1998-99\end{array}$ & 36 & 911 & 1.36 & -- \\
\hline 03301500 & Rolling Fork near Boston & 1,299 & 37.767 & 85.704 & 775 & $1938-99$ & 61 & 1,820 & 1.40 & -- \\
\hline 03301580 & Wilson Creek near Deatsville & 12.3 & 37.864 & 85.611 & 697 & 1992-96 & 5 & 18.9 & 1.54 & -- \\
\hline 03302000 & Pond Creek near Louisville & 64.0 & 38.120 & 85.796 & 542 & $1945-99$ & 55 & 90.7 & 1.42 & $\begin{array}{l}\text { LD - waste disposal, } \\
\text { urban drainage, } \\
\text { Louisville }\end{array}$ \\
\hline 03302220 & $\begin{array}{l}\text { Buck Creek near New Middletown, } \\
\text { Indiana }\end{array}$ & 65.2 & 38.119 & 86.086 & 750 & $1970-99$ & 30 & 78.2 & 1.20 & -- \\
\hline 03302300 & $\begin{array}{l}\text { Little Indian Creek near Galena, } \\
\text { Indiana }\end{array}$ & 16.1 & 38.312 & 85.898 & 814 & $1969-99$ & 31 & 22.7 & 1.41 & - \\
\hline 03303000 & Blue River near White Cloud, Indiana & 476 & 38.237 & 86.228 & 754 & 1932-99 & 68 & 657 & 1.38 & -- \\
\hline 03303280 & Ohio River at Cannelton Dam & 97,000 & 37.899 & 86.706 & -- & $1976-99$ & 24 & ${ }^{2} 123,000$ & 1.27 & Various \\
\hline
\end{tabular}


Table 1. Continuous-record streamflow-gaging stations used in the study, selected basin characteristics, periods of record used in the analysis, corresponding mean annual flows, and selected reservoirs and diversions in the basin for Kentucky and surrounding States-Continued

$\left[\mathrm{mi}^{2}\right.$, square miles; $\mathrm{ft}^{3} / \mathrm{s}$, cubic feet per second; $\mathrm{ft}^{3} / \mathrm{s} / \mathrm{mi}^{2}$, cubic feet per second per square mile; --, not applicable; LD, local diversion; all stations are in Kentucky unless otherwise noted]

\begin{tabular}{|c|c|c|c|c|c|c|c|c|c|c|}
\hline $\begin{array}{l}\text { Station } \\
\text { number }\end{array}$ & Station name & $\begin{array}{l}\text { Total } \\
\text { drainage } \\
\text { area } \\
\left(\mathrm{mi}^{2}\right)\end{array}$ & $\begin{array}{c}\text { Gage } \\
\text { latitude } \\
\text { (decimal } \\
\text { degrees) }\end{array}$ & $\begin{array}{c}\text { Gage } \\
\text { longitude } \\
\text { (decimal } \\
\text { degrees) }\end{array}$ & $\begin{array}{c}\text { Mean } \\
\text { basin } \\
\text { elevation } \\
\text { (feet } \\
\text { above } \\
\text { sea level) }\end{array}$ & $\begin{array}{l}\text { Period of } \\
\text { record used } \\
\text { in the } \\
\text { analysis } \\
\text { (water } \\
\text { years }{ }^{1} \text { ) }\end{array}$ & $\begin{array}{c}\text { Number } \\
\text { of } \\
\text { years }\end{array}$ & $\begin{array}{c}\text { Mean } \\
\text { annual } \\
\text { flow } \\
\left(\mathrm{ft}^{3} / \mathrm{s}\right)\end{array}$ & $\begin{array}{c}\text { Standardized } \\
\text { mean annual } \\
\text { flow } \\
\left(\mathrm{ft}^{3} / \mathrm{s} / \mathrm{mi}^{2}\right)\end{array}$ & $\begin{array}{l}\text { Selected reservoirs } \\
\text { in basin and } \\
\text { start date or type of } \\
\text { local diversion and } \\
\text { location }\end{array}$ \\
\hline 03303400 & $\begin{array}{l}\text { Crooked Creek near Santa Claus, } \\
\text { Indiana }\end{array}$ & 7.86 & 38.118 & 86.890 & 495 & $1970-99$ & 30 & 11.1 & 1.42 & $\cdots$ \\
\hline 03303500 & Ohio River at Owensboro & 97,200 & 37.778 & 87.109 & -- & $1941-52$ & 12 & ${ }^{2} 125,000$ & 1.29 & Various \\
\hline 03304500 & McGills Creek near McKinney & 2.14 & 37.444 & 84.698 & 1,194 & $1952-71$ & 20 & 2.58 & 1.20 & -- \\
\hline 03305000 & Green River near McKinney & 22.4 & 37.422 & 84.750 & 1,150 & $1952-73$ & 22 & 31.5 & 1.41 & -- \\
\hline 03305500 & Green River near Mount Salem & 36.3 & 37.411 & 84.753 & 1,151 & $1954-61$ & 8 & 54.0 & 1.49 & -- \\
\hline 03306000 & Green River near Campbellsville & 682 & 37.240 & 85.347 & 951 & $\begin{array}{l}1931 \\
1964-94\end{array}$ & 32 & 1,120 & 1.64 & $\begin{array}{l}\text { Green River Lake, } \\
02 / 69\end{array}$ \\
\hline 03306500 & Green River at Greensburg & 736 & 37.254 & 85.503 & 933 & $1940-75$ & 36 & 1,120 & 1.53 & $\begin{array}{l}\text { Green River Lake, } \\
02 / 69\end{array}$ \\
\hline 03307000 & Russell Creek near Columbia & 188 & 37.119 & 85.394 & 876 & $1940-99$ & 60 & 292 & 1.55 & - \\
\hline 03307100 & Russell Creek near Gresham & 265 & 37.168 & 85.470 & 842 & $1965-75$ & 11 & 451 & 1.70 & -- \\
\hline 03307500 & $\begin{array}{l}\text { South Fork Little Barren River at } \\
\text { Edmonton }\end{array}$ & 18.3 & 36.974 & 85.603 & 899 & $1942-72$ & 31 & 26.3 & 1.44 & - \\
\hline 03308500 & Green River at Munfordville & 1,673 & 37.268 & 85.886 & 855 & $\begin{array}{l}1916-22 \\
1928-31 \\
1938-99\end{array}$ & 73 & 2,740 & 1.64 & $\begin{array}{l}\text { Green River Lake, } \\
02 / 69\end{array}$ \\
\hline 03309000 & Green River at Mammoth Cave & 1,983 & 37.179 & 86.113 & 835 & $1939-50$ & 12 & 2,880 & 1.45 & - \\
\hline 03309500 & McDougal Creek near Hodgenville & 5.34 & 37.544 & 85.672 & 883 & $1954-71$ & 18 & 7.00 & 1.31 & - \\
\hline 03310000 & $\begin{array}{l}\text { North Fork Nolin River at } \\
\text { Hodgenville }\end{array}$ & 36.4 & 37.576 & 85.740 & 844 & $1942-73$ & 32 & 46.9 & 1.29 & - \\
\hline 03310300 & Nolin River at White Mills & 357 & 37.551 & 86.045 & 769 & $1960-99$ & 40 & 492 & 1.38 & - \\
\hline 03310400 & Bacon Creek near Priceville & 85.4 & 37.359 & 85.998 & 775 & $1960-94$ & 35 & 58.4 & .68 & - \\
\hline 03310500 & Nolin River at Wax & 600 & 37.345 & 86.122 & 749 & $1937-62$ & 26 & 793 & 1.32 & -- \\
\hline 03311000 & Nolin River at Kyrock & 703 & 37.274 & 86.251 & 736 & $\begin{array}{l}1931 \\
1940-50 \\
1961-99\end{array}$ & 51 & 942 & 1.34 & Nolin Lake, 03/63 \\
\hline 03311500 & Green River at Lock 6 at Brownsville & 2,762 & 37.207 & 86.261 & 805 & $\begin{array}{l}1925-31 \\
1939-92\end{array}$ & 61 & 4,370 & 1.58 & $\begin{array}{l}\text { Nolin Lake, 03/63; } \\
\text { Green River Lake, } \\
02 / 69\end{array}$ \\
\hline 03311600 & Beaverdam Creek at Rhoda & 10.9 & 37.155 & 86.226 & 673 & $1973-94$ & 22 & 18.2 & 1.66 & - \\
\hline
\end{tabular}


\& Table 1. Continuous-record streamflow-gaging stations used in the study, selected basin characteristics, periods of record used in the analysis,

corresponding mean annual flows, and selected reservoirs and diversions in the basin for Kentucky and surrounding States-Continued

[ $\mathrm{mi}^{2}$, square miles; $\mathrm{ft}^{3} / \mathrm{s}$, cubic feet per second; $\mathrm{ft}^{3} / \mathrm{s} / \mathrm{mi}^{2}$, cubic feet per second per square mile; --, not applicable; LD, local diversion; all stations are in Kentucky unless otherwise noted]

\begin{tabular}{|c|c|c|c|c|c|c|c|c|c|c|}
\hline $\begin{array}{l}\text { Station } \\
\text { number }\end{array}$ & Station name & $\begin{array}{l}\text { Total } \\
\text { drainage } \\
\text { area } \\
\left(\mathrm{mi}^{2}\right)\end{array}$ & $\begin{array}{c}\text { Gage } \\
\text { latitude } \\
\text { (decimal } \\
\text { degrees) }\end{array}$ & $\begin{array}{c}\text { Gage } \\
\text { longitude } \\
\text { (decimal } \\
\text { degrees) }\end{array}$ & $\begin{array}{l}\text { Mean } \\
\text { basin } \\
\text { elevation } \\
\text { (feet } \\
\text { above } \\
\text { sea level) }\end{array}$ & $\begin{array}{l}\text { Period of } \\
\text { record used } \\
\text { in the } \\
\text { analysis } \\
\text { (water } \\
\text { years') }\end{array}$ & $\begin{array}{c}\text { Number } \\
\text { of } \\
\text { years }\end{array}$ & $\begin{array}{c}\text { Mean } \\
\text { annual } \\
\text { flow } \\
\left(\mathrm{ft}^{3} / \mathrm{s}\right)\end{array}$ & $\begin{array}{c}\text { Standardized } \\
\text { mean annual } \\
\text { flow } \\
\left(\mathrm{ft}^{3} / \mathrm{s} / \mathrm{mi}^{2}\right)\end{array}$ & $\begin{array}{c}\text { Selected reservoirs } \\
\text { in basin and } \\
\text { start date or type of } \\
\text { local diversion and } \\
\text { location }\end{array}$ \\
\hline 03312000 & Bear Creek near Leitchfield & 30.8 & 37.427 & 86.279 & 677 & $1950-71$ & 22 & 42.7 & 1.39 & -- \\
\hline 03312500 & Barren River near Pageville & 531 & 36.852 & 86.077 & 827 & $1940-63$ & 24 & 844 & 1.59 & -- \\
\hline 03312765 & $\begin{array}{l}\text { Beaver Creek at Highway } 31 \text { East } \\
\text { near Glasgow }\end{array}$ & 49.6 & 37.035 & 85.904 & 838 & $1992-99$ & 8 & 97.5 & 1.96 & -- \\
\hline 03313000 & Barren River near Finney & 942 & 36.895 & 86.134 & 804 & $\begin{array}{l}1942-50 \\
1961-94\end{array}$ & 43 & 1,500 & 1.59 & $\begin{array}{l}\text { Barren River Lake, } \\
03 / 64\end{array}$ \\
\hline 03313500 & West Bays Fork at Scottsville & 7.47 & 36.748 & 86.196 & 785 & $1951-72$ & 22 & 10.8 & 1.45 & -- \\
\hline 03313700 & $\begin{array}{l}\text { West Fork Drakes Creek near } \\
\text { Franklin }\end{array}$ & 110 & 36.719 & 86.546 & 783 & $1969-99$ & 31 & 194 & 1.77 & -- \\
\hline 03314000 & Drakes Creek near Alvaton & 478 & 36.895 & 86.381 & 724 & $1941-71$ & 31 & 697 & 1.46 & - \\
\hline 03314500 & Barren River at Bowling Green & 1,849 & 37.001 & 86.431 & 743 & $1939-94$ & 56 & 2,600 & 1.41 & $\begin{array}{l}\text { Barren River Lake, } \\
03 / 64\end{array}$ \\
\hline 03315000 & Barren River at Lock 1 at Greencastle & 1,966 & 37.086 & 86.503 & 733 & $1925-31$ & 7 & 2,500 & 1.27 & -- \\
\hline 03315500 & Green River at Lock 4 at Woodbury & 5,404 & 37.182 & 86.630 & -- & $1938-92$ & 55 & 8,460 & 1.57 & $\begin{array}{l}\text { Nolin Lake, 03/63; } \\
\text { Barren River Lake, } \\
\text { 03/64; } \\
\text { Green River Lake, } \\
\text { 02/69 }\end{array}$ \\
\hline 03316000 & Mud River near Lewisburg & 90.5 & 37.004 & 86.907 & 599 & $1940-72$ & 33 & 151 & 1.67 & -. \\
\hline 03316500 & Green River at Paradise & 6,183 & 37.265 & 86.979 & -- & $\begin{array}{l}1940-50 \\
1961-81 \\
1992-99\end{array}$ & 40 & 9,360 & 1.51 & $\begin{array}{l}\text { Nolin Lake, 03/63; } \\
\text { Barren River Lake, } \\
\text { 03/64; } \\
\text { Green River Lake, } \\
\text { 02/69 }\end{array}$ \\
\hline 03317000 & Rough River near Madrid & 225 & 37.592 & 86.329 & 711 & $1939-59$ & 21 & 318 & 1.41 & - \\
\hline 03317500 & $\begin{array}{l}\text { North Fork Rough River near } \\
\text { Westview }\end{array}$ & 42.0 & 37.692 & 86.391 & 711 & $1955-73$ & 19 & 36.7 & .87 & -- \\
\hline 03318000 & Rough River near Falls of Rough & 454 & 37.609 & 86.496 & 685 & $1940-51$ & 12 & 627 & 1.38 & -- \\
\hline 03318200 & Rock Lick Creek near Glen Dean & 20.1 & 37.657 & 86.562 & 617 & $1957-71$ & 15 & 24.9 & 1.24 & -. \\
\hline 03318500 & Rough River at Falls of Rough & 504 & 37.589 & 86.551 & 676 & $1949-94$ & 46 & 759 & 1.51 & $\begin{array}{l}\text { Rough River Lake, } \\
10 / 59\end{array}$ \\
\hline 03318800 & Caney Creek near Horse Branch & 124 & 37.464 & 86.656 & 606 & $1957-92$ & 36 & 188 & 1.52 & -- \\
\hline
\end{tabular}


Table 1. Continuous-record streamflow-gaging stations used in the study, selected basin characteristics, periods of record used in the analysis, corresponding mean annual flows, and selected reservoirs and diversions in the basin for Kentucky and surrounding States-Continued

$\left[\mathrm{mi}^{2}\right.$, square miles; $\mathrm{ft}^{3} / \mathrm{s}$, cubic feet per second; $\mathrm{ft}^{3} / \mathrm{s} / \mathrm{mi}^{2}$, cubic feet per second per square mile; --, not applicable; $\mathrm{LD}$, local diversion; all stations are in Kentucky unless otherwise noted]

\begin{tabular}{|c|c|c|c|c|c|c|c|c|c|c|}
\hline $\begin{array}{l}\text { Station } \\
\text { number }\end{array}$ & Station name & $\begin{array}{l}\text { Total } \\
\text { drainage } \\
\text { area } \\
\left(\mathrm{mi}^{2}\right)\end{array}$ & $\begin{array}{c}\text { Gage } \\
\text { latitude } \\
\text { (decimal } \\
\text { degrees) }\end{array}$ & $\begin{array}{c}\text { Gage } \\
\text { longitude } \\
\text { (decimal } \\
\text { degrees) }\end{array}$ & $\begin{array}{c}\text { Mean } \\
\text { basin } \\
\text { elevation } \\
\text { (feet } \\
\text { above } \\
\text { sea level) }\end{array}$ & $\begin{array}{l}\text { Period of } \\
\text { record used } \\
\text { in the } \\
\text { analysis } \\
\text { (water } \\
\text { years }{ }^{1} \text { ) }\end{array}$ & $\begin{array}{c}\text { Number } \\
\text { of } \\
\text { years }\end{array}$ & $\begin{array}{c}\text { Mean } \\
\text { annual } \\
\text { flow } \\
\left(\mathrm{ft}^{3} / \mathrm{s}\right)\end{array}$ & $\begin{array}{c}\text { Standardized } \\
\text { mean annual } \\
\text { flow } \\
\left(\mathrm{ft}^{3} / \mathrm{s} / \mathrm{mi}^{2}\right)\end{array}$ & $\begin{array}{c}\text { Selected reservoirs } \\
\text { in basin and } \\
\text { start date or type of } \\
\text { local diversion and } \\
\text { location }\end{array}$ \\
\hline 03319000 & Rough River near Dundee & 757 & 37.547 & 86.722 & 647 & $1941-92$ & 52 & 1,080 & 1.43 & $\begin{array}{l}\text { Rough River Lake, } \\
\quad 10 / 59\end{array}$ \\
\hline 03320000 & Green River at Lock 2 at Calhoun & 7,566 & 37.534 & 87.264 & -- & $1931-99$ & 69 & 11,200 & 1.48 & $\begin{array}{l}\text { Rough River Lake, } \\
\text { 10/59; } \\
\text { Nolin Lake, 03/63; } \\
\text { Barren River Lake, } \\
\text { 03/64; } \\
\text { Green River Lake, } \\
\text { 02/69 }\end{array}$ \\
\hline 03320500 & Pond River near Apex & 194 & 37.122 & 87.319 & 599 & $1941-99$ & 59 & 274 & 1.41 & -- \\
\hline 03321000 & Pond River near White Plains & 343 & 37.227 & 87.349 & 562 & $\begin{array}{l}1929-31 \\
1938-40\end{array}$ & 6 & 370 & 1.08 & -- \\
\hline 03321060 & Pond River near Madisonville & 469 & 37.317 & 87.369 & 535 & $1992-96$ & 5 & 381 & .81 & - \\
\hline 03321210 & Cypress Creek near Madisonville & 14.2 & 37.489 & 87.286 & 437 & $\begin{array}{l}\text { 1980-81, } \\
1991-94\end{array}$ & 6 & 160 & 1.13 & - \\
\hline 03321350 & $\begin{array}{l}\text { South Fork Panther Creek near } \\
\text { Whitesville }\end{array}$ & 58.2 & 37.619 & 86.887 & 556 & $1969-83$ & 15 & 96.9 & 1.66 & - \\
\hline 03322000 & Ohio River at Evansville, Indiana & 107,000 & 37.972 & 87.576 & - & $1941-74$ & 34 & 133,000 & 1.24 & Various \\
\hline 03322100 & Pigeon Creek at Evansville, Indiana & 323 & 38.004 & 87.539 & 443 & $1961-84$ & 24 & 369 & 1.14 & -- \\
\hline 03322360 & Beaverdam Creek near Corydon & 14.3 & 37.704 & 87.698 & 446 & $\begin{array}{l}\text { 1973-82, } \\
1984-86, \\
1989-94\end{array}$ & 19 & 14.8 & 1.04 & -- \\
\hline 03322420 & Ohio River at Uniontown Dam & 108,000 & 37.792 & 87.986 & - & $1985-93$ & 9 & ${ }^{2} 138,000$ & 1.28 & Various \\
\hline 03366200 & Herberts Creek near Madison, Indiana & 9.31 & 38.782 & 85.486 & 826 & $1969-99$ & 31 & 13.5 & 1.45 & - \\
\hline 03378550 & Big Creek near Wadesville, Indiana & 104 & 38.082 & 87.769 & 456 & $1966-99$ & 34 & 116 & 1.11 & -- \\
\hline 03383000 & Tradewater River at Olney & 255 & 37.224 & 87.781 & 532 & $\begin{array}{l}1941-83 \\
1986-99\end{array}$ & 57 & 334 & 1.31 & -- \\
\hline 03383500 & Tradewater River near Dalton & 283 & 37.274 & 87.797 & 526 & $\begin{array}{l}1929-31 \\
1938-40\end{array}$ & 6 & 284 & 1.00 & $\cdots$ \\
\hline 03384000 & Rose Creek at Nebo & 2.10 & 37.383 & 87.633 & 423 & $1953-70$ & 18 & 1.99 & .95 & -- \\
\hline 03384500 & $\begin{array}{l}\text { Ohio River at Dam } 51 \text {, at Golconda, } \\
\text { Illinois }\end{array}$ & 143,900 & 37.358 & 88.482 & - & $1941-52$ & 12 & ${ }^{3} 173,000$ & 1.20 & Various \\
\hline 03400500 & Poor Fork at Cumberland & 82.3 & 36.974 & 82.993 & 2,399 & $1941-93$ & 53 & 143 & 1.73 & - \\
\hline
\end{tabular}


Table 1. Continuous-record streamflow-gaging stations used in the study, selected basin characteristics, periods of record used in the analysis, corresponding mean annual flows, and selected reservoirs and diversions in the basin for Kentucky and surrounding States-Continued

$\left[\mathrm{mi}^{2}\right.$, square miles; $\mathrm{ft}^{3} / \mathrm{s}$, cubic feet per second; $\mathrm{ft}^{3} / \mathrm{s} / \mathrm{mi}^{2}$, cubic feet per second per square mile; --, not applicable; LD, local diversion; all stations are in Kentucky unless otherwise noted]

\begin{tabular}{|c|c|c|c|c|c|c|c|c|c|c|}
\hline $\begin{array}{l}\text { Station } \\
\text { number }\end{array}$ & Station name & $\begin{array}{l}\text { Total } \\
\text { drainage } \\
\text { area } \\
\left(\mathrm{mi}^{2}\right)\end{array}$ & $\begin{array}{c}\text { Gage } \\
\text { latitude } \\
\text { (decimal } \\
\text { degrees) }\end{array}$ & $\begin{array}{c}\text { Gage } \\
\text { longitude } \\
\text { (decimal } \\
\text { degrees) }\end{array}$ & $\begin{array}{c}\text { Mean } \\
\text { basin } \\
\text { elevation } \\
\text { (feet } \\
\text { above } \\
\text { sea level) }\end{array}$ & $\begin{array}{l}\text { Period of } \\
\text { record used } \\
\text { in the } \\
\text { analysis } \\
\text { (water } \\
\text { years') }\end{array}$ & $\begin{array}{c}\text { Number } \\
\text { of } \\
\text { years }\end{array}$ & $\begin{array}{c}\text { Mean } \\
\text { annual } \\
\text { flow } \\
\left(\mathrm{ft}^{3} / \mathrm{s}\right)\end{array}$ & $\begin{array}{c}\text { Standardized } \\
\text { mean annual } \\
\text { flow } \\
\left(\mathrm{ft}^{3} / \mathrm{s} / \mathrm{mi}^{2}\right)\end{array}$ & $\begin{array}{l}\text { Selected reservoirs } \\
\text { in basin and } \\
\text { start date or type of } \\
\text { local diversion and } \\
\text { location }\end{array}$ \\
\hline 03400785 & Martins Fork above Smith & 23.8 & 36.726 & 83.288 & 2,185 & $1986-90$ & 5 & 47.0 & 1.98 & - \\
\hline 03400800 & Martins Fork near Smith & 55.8 & 36.749 & 83.248 & 2,077 & $1972-99$ & 28 & 119 & 2.12 & $\begin{array}{l}\text { Martins Fork Lake, } \\
\quad 11 / 78\end{array}$ \\
\hline 03400990 & Clover Fork at Harlan & 222 & 36.848 & 83.326 & 2,181 & $1979-92$ & 14 & 403 & 1.81 & $\begin{array}{l}\text { Martins Fork Lake, } \\
\quad 11 / 78\end{array}$ \\
\hline 03401000 & Cumberland River near Harlan & 374 & 36.847 & 83.356 & 2,219 & $1941-99$ & 59 & 695 & 1.86 & $\begin{array}{l}\text { Martins Fork Lake, } \\
\quad 11 / 78\end{array}$ \\
\hline 03402000 & Yellow Creek near Middlesboro & 60.6 & 36.668 & 83.689 & 1,815 & $1941-99$ & 59 & 120 & 1.98 & $\begin{array}{l}\text { LD - water supply, } \\
\text { waste disposal, } \\
\text { Middlesboro } \\
\text { (minor) }\end{array}$ \\
\hline 03402900 & $\begin{array}{l}\text { Cumberland River at Pine Street } \\
\text { Bridge at Pineville }\end{array}$ & 770 & 36.763 & 83.692 & 1,971 & $1992-99$ & 8 & 1,480 & 1.92 & $\begin{array}{l}\text { Martins Fork Lake, } \\
11 / 78\end{array}$ \\
\hline 03403000 & Cumberland River near Pineville & 809 & 36.813 & 83.766 & 1,943 & $\begin{array}{l}1939-75 \\
1980-91\end{array}$ & 49 & 1,400 & 1.73 & $\begin{array}{l}\text { Martins Fork Lake, } \\
11 / 78 \text {; } \\
\text { LD - power plant } \\
\text { (minor) }\end{array}$ \\
\hline 03403500 & Cumberland River at Barbourville & 960 & 36.862 & 83.887 & 1,850 & $\begin{array}{l}\text { 1923-31, } \\
1949-92, \\
1996-99\end{array}$ & 57 & 1,770 & 1.84 & $\begin{array}{l}\text { Martins Fork Lake, } \\
\text { 11/78; } \\
\text { LD - water supply, } \\
\text { Barbourville (minor) }\end{array}$ \\
\hline 03403910 & Clear Fork at Saxton & 331 & 36.634 & 84.112 & 1,633 & $\begin{array}{l}1969-90 \\
1996-99\end{array}$ & 26 & 557 & 1.68 & -- \\
\hline 03404000 & Cumberland River at Williamsburg & 1,607 & 36.744 & 84.158 & 1,679 & $1951-99$ & 49 & 2,730 & 1.70 & $\begin{array}{l}\text { Martins Fork Lake, } \\
\quad 11 / 78\end{array}$ \\
\hline 03404500 & $\begin{array}{l}\text { Cumberland River at } \\
\text { Cumberland Falls }\end{array}$ & 1,977 & 36.837 & 84.343 & 1,603 & $\begin{array}{l}\text { 1908-11, } \\
1916-31 \\
1933-94\end{array}$ & 82 & 3,190 & 1.61 & $\begin{array}{l}\text { Martins Fork Lake, } \\
11 / 78\end{array}$ \\
\hline 03404820 & $\begin{array}{l}\text { Laurel River at Municipal Dam near } \\
\text { Corbin }\end{array}$ & 140 & 36.970 & 87.120 & 1,204 & $1974-92$ & 19 & 238 & 1.70 & $\begin{array}{l}\text { LD - water supply, } \\
\text { Corbin (minor) }\end{array}$ \\
\hline 03404900 & Lynn Camp Creek at Corbin & 53.8 & 36.951 & 84.094 & 1,218 & $1974-99$ & 26 & 88.9 & 1.65 & - \\
\hline 03405000 & Laurel River at Corbin & 201 & 36.969 & 84.127 & 1,206 & $\begin{array}{l}1923-24 \\
1943-73\end{array}$ & 33 & 338 & 1.68 & $\begin{array}{l}\text { LD - water supply, } \\
\text { Corbin (minor) }\end{array}$ \\
\hline 03406000 & Wood Creek near London & 3.89 & 37.161 & 84.112 & 1,238 & $1954-71$ & 18 & 5.34 & 1.37 & -- \\
\hline
\end{tabular}


Table 1. Continuous-record streamflow-gaging stations used in the study, selected basin characteristics, periods of record used in the analysis, corresponding mean annual flows, and selected reservoirs and diversions in the basin for Kentucky and surrounding States-Continued

$\left[\mathrm{mi}^{2}\right.$, square miles; $\mathrm{ft}^{3} / \mathrm{s}$, cubic feet per second; $\mathrm{ft}^{3} / \mathrm{s} / \mathrm{mi}^{2}$, cubic feet per second per square mile; --, not applicable; LD, local diversion; all stations are in Kentucky unless otherwise noted]

\begin{tabular}{|c|c|c|c|c|c|c|c|c|c|c|}
\hline $\begin{array}{l}\text { Station } \\
\text { number }\end{array}$ & Station name & $\begin{array}{l}\text { Total } \\
\text { drainage } \\
\text { area } \\
\left(\mathrm{mi}^{2}\right)\end{array}$ & $\begin{array}{c}\text { Gage } \\
\text { latitude } \\
\text { (decimal } \\
\text { degrees) }\end{array}$ & $\begin{array}{c}\text { Gage } \\
\text { longitude } \\
\text { (decimal } \\
\text { degrees) }\end{array}$ & $\begin{array}{c}\text { Mean } \\
\text { basin } \\
\text { elevation } \\
\text { (feet } \\
\text { above } \\
\text { sea level) }\end{array}$ & $\begin{array}{l}\text { Period of } \\
\text { record used } \\
\text { in the } \\
\text { analysis } \\
\text { (water } \\
\text { years') }\end{array}$ & $\begin{array}{c}\text { Number } \\
\text { of } \\
\text { years }\end{array}$ & $\begin{array}{c}\text { Mean } \\
\text { annual } \\
\text { flow } \\
\left(\mathrm{ft}^{3} / \mathrm{s}\right)\end{array}$ & $\begin{array}{c}\text { Standardized } \\
\text { mean annual } \\
\text { flow } \\
\left(\mathrm{ft}^{3} / \mathrm{s} / \mathrm{mi}^{2}\right)\end{array}$ & $\begin{array}{l}\text { Selected reservoirs } \\
\text { in basin and } \\
\text { start date or type of } \\
\text { local diversion and } \\
\text { location }\end{array}$ \\
\hline 03406500 & Rockcastle River at Billows & 604 & 37.171 & 84.296 & 1,178 & $1937-99$ & 63 & 945 & 1.57 & -- \\
\hline 03407000 & $\begin{array}{l}\text { Rockcastle River at } \\
\text { Rockcastle Springs }\end{array}$ & 745 & 37.010 & 84.315 & 1,163 & $1923-31$ & 9 & 1,090 . & 1.47 & -- \\
\hline 03407100 & Cane Branch near Parkers Lake & .67 & 36.868 & 84.449 & 1,216 & $\begin{array}{l}1957-66 \\
1974\end{array}$ & 11 & .92 & 1.37 & - \\
\hline 03407300 & Helton Branch near Greenwood & .85 & 36.885 & 84.482 & 1,217 & $1957-74$ & 18 & 1.22 & 1.43 & $-\cdot$ \\
\hline 03407500 & Buck Creek near Shopville & 165 & 37.211 & 84.464 & 1,116 & $1953-91$ & 39 & 277 & 1.68 & -- \\
\hline 03410500 & $\begin{array}{l}\text { South Fork Cumberland River near } \\
\text { Sterns }\end{array}$ & 954 & 36.627 & 84.533 & 1,605 & $1943-99$ & 57 & 1,790 & 1.88 & -- \\
\hline 03411000 & $\begin{array}{l}\text { South Fork Cumberland River at } \\
\text { Nevelsville }\end{array}$ & 1,271 & 36.840 & 84.583 & 1,501 & $\begin{array}{l}1916-31 \\
1933-50\end{array}$ & 34 & 2,200 & 1.73 & -- \\
\hline 03411500 & Cumberland River at Burnside & 4,865 & 36.989 & 84.610 & -- & $1915-50$ & 36 & 7,630 & 1.57 & $\begin{array}{l}\text { Laurel River Lake, } \\
\text { 10/73; } \\
\text { Martins Fork Lake, } \\
\text { 11/78 }\end{array}$ \\
\hline 03412000 & Pitman Creek near Somerset & 26.3 & 37.135 & 84.588 & 1,082 & $1951-53$ & 3 & 47.9 & 1.82 & - \\
\hline 03413200 & Beaver Creek near Monticello & 43.4 & 36.797 & 84.896 & 1,212 & $\begin{array}{l}1969-83 \\
1990-99\end{array}$ & 25 & 64.1 & 1.48 & -- \\
\hline 03414000 & Cumberland River near Rowena & 5,790 & 36.884 & 85.139 & -- & $1940-92$ & 53 & 9,010 & 1.56 & $\begin{array}{l}\text { Cumberland Lake, } \\
\text { 12/50; } \\
\text { Laurel River Lake, } \\
\text { 10/73; } \\
\text { Martins Fork Lake, } \\
\text { 11/78 }\end{array}$ \\
\hline 03414500 & $\begin{array}{l}\text { East Fork Obey River near } \\
\text { Jamestown, Tennessee }\end{array}$ & 202 & 36.416 & 85.026 & 1,645 & $1943-91$ & 49 & 418 & 2.07 & -- \\
\hline 03415000 & $\begin{array}{l}\text { West Fork Obey River near Alpine, } \\
\text { Tennessee }\end{array}$ & 115 & 36.397 & 85.174 & 1,391 & $\begin{array}{l}1943-71 \\
1980-81\end{array}$ & 31 & 157 & 1.37 & - \\
\hline 03416000 & $\begin{array}{l}\text { Wolf River near Byrdstown, } \\
\text { Tennessee }\end{array}$ & 106 & 36.560 & 85.073 & 1,319 & $1943-91$ & 49 & 189 & 1.78 & -. \\
\hline 03418000 & $\begin{array}{l}\text { Roaring River near Hilham, } \\
\text { Tennessee }\end{array}$ & 78.7 & 36.341 & 85.426 & 1,112 & $1932-74$ & 43 & 109 & 1.39 & $\cdots$ \\
\hline 03435140 & Whippoorwill Creek near Claymour & 20.8 & 36.875 & 87.089 & 719 & $1974-91$ & 18 & 34.7 & 1.67 & -- \\
\hline 03435500 & Red River near Adams, Tennessee & 706 & 36.589 & 87.089 & 652 & $1921-69$ & 49 & 937 & 1.33 & -- \\
\hline
\end{tabular}


\$ Table 1. Continuous-record streamflow-gaging stations used in the study, selected basin characteristics, periods of record used in the analysis,

corresponding mean annual flows, and selected reservoirs and diversions in the basin for Kentucky and surrounding States-Continued

$\left[\mathrm{mi}^{2}\right.$, square miles; $\mathrm{ft}^{3} / \mathrm{s}$, cubic feet per second; $\mathrm{ft}^{3} / \mathrm{s} / \mathrm{mi}^{2}$, cubic feet per second per square mile; --, not applicable; LD, local diversion; all stations are in Kentucky unless otherwise noted]

\begin{tabular}{|c|c|c|c|c|c|c|c|c|c|c|}
\hline $\begin{array}{l}\text { Station } \\
\text { number }\end{array}$ & Station name & $\begin{array}{l}\text { Total } \\
\text { drainage } \\
\text { area } \\
\left(\mathrm{mi}^{2}\right)\end{array}$ & $\begin{array}{c}\text { Gage } \\
\text { latitude } \\
\text { (decimal } \\
\text { degrees) }\end{array}$ & $\begin{array}{c}\text { Gage } \\
\text { longitude } \\
\text { (decimal } \\
\text { degrees) }\end{array}$ & $\begin{array}{c}\text { Mean } \\
\text { basin } \\
\text { elevation } \\
\text { (feet } \\
\text { above } \\
\text { sea level) }\end{array}$ & $\begin{array}{l}\text { Period of } \\
\text { record used } \\
\text { in the } \\
\text { analysis } \\
\text { (water } \\
\text { years' } \\
\text { ') }\end{array}$ & $\begin{array}{c}\text { Number } \\
\text { of } \\
\text { years }\end{array}$ & $\begin{array}{c}\text { Mean } \\
\text { annual } \\
\text { flow } \\
\left(\mathrm{ft}^{3} / \mathrm{s}\right)\end{array}$ & $\begin{array}{c}\text { Standardized } \\
\text { mean annual } \\
\text { flow } \\
\left(\mathrm{ft}^{3} / \mathrm{s} / \mathrm{mi}^{2}\right)\end{array}$ & $\begin{array}{c}\text { Selected reservoirs } \\
\text { in basin and } \\
\text { start date or type of } \\
\text { local diversion and } \\
\text { location }\end{array}$ \\
\hline 03436000 & $\begin{array}{l}\text { Sulfur Fork Red River near Adams, } \\
\text { Tennessee }\end{array}$ & 186 & 36.515 & 87.059 & 682 & $1940-91$ & 52 & 252 & 1.35 & -- \\
\hline 03436700 & Yellow Creek near Shiloh, Tennessee & 124 & 36.349 & 87.539 & 677 & $1958-80$ & 23 & 191 & 1.54 & -- \\
\hline 03437500 & $\begin{array}{l}\text { South Fork Little River at } \\
\text { Hopkinsville }\end{array}$ & 46.5 & 36.839 & 87.481 & 618 & $1950-73$ & 24 & 65.8 & 1.42 & - \\
\hline 03438000 & Little River near Cadiz & 244 & 36.778 & 87.722 & 578 & $1941-99$ & 59 & 356 & 1.46 & - \\
\hline 03438070 & $\begin{array}{l}\text { Muddy Fork Little River near } \\
\text { Cerulean }\end{array}$ & 30.5 & 36.978 & 87.710 & 569 & $1969-83$ & 15 & 50.2 & 1.65 & -- \\
\hline 03438220 & Cumberland River near Grand Rivers & 17,600 & 37.021 & 88.221 & -- & $1967-97$ & 31 & ${ }^{4} 38,200$ & 2.17 & $\begin{array}{l}\text { Dale Hollow Lake, } \\
\text { 08/43; } \\
\text { Lake Barkley, 08/44; } \\
\text { Cumberland Lake, } \\
\text { 12/50; } \\
\text { various others }\end{array}$ \\
\hline 03529500 & $\begin{array}{l}\text { Powell River at Big Stone Gap, } \\
\text { Virginia }\end{array}$ & 112 & 36.870 & 82.780 & 2,414 & $\begin{array}{l}1945-59 \\
1979-81\end{array}$ & 18 & 202 & 1.80 & -- \\
\hline 03530500 & $\begin{array}{l}\text { North Fork Powell River at } \\
\text { Pennington Gap, Virginia }\end{array}$ & 70 & 36.770 & 83.030 & 2,109 & $\begin{array}{l}\text { 1946-51, } \\
1979-81, \\
1994-95\end{array}$ & 11 & 137 & 1.95 & -- \\
\hline 03531000 & $\begin{array}{l}\text { Powell River near Pennington Gap, } \\
\quad \text { Virginia }\end{array}$ & 290 & 36.734 & 82.999 & 2,161 & $1921-31$ & 11 & 553 & 1.91 & - \\
\hline 03531500 & Powell River near Jonesville, Virginia & 319 & 36.660 & 83.090 & 2,101 & $1932-99$ & 68 & 543 & 1.70 & -- \\
\hline 03609500 & Tennessee River near Paducah & 40,200 & 37.020 & 88.281 & -- & $1967-84$ & 18 & ${ }^{4} 66,900$ & 1.66 & $\begin{array}{l}\text { Kentucky Lake, 01/36; } \\
\text { various others }\end{array}$ \\
\hline 03610000 & Clarks River at Murray & 89.7 & 36.593 & 88.300 & 553 & $1952-71$ & 20 & 88.6 & .99 & -- \\
\hline 03610200 & Clarks River at Almo & 134 & 36.692 & 88.274 & 540 & $1983-99$ & 17 & 181 & 1.35 & $\begin{array}{l}\text { LD - waste-disposal, } \\
\text { Murray }\end{array}$ \\
\hline 03610500 & Clarks River near Benton & 227 & 36.873 & 88.347 & 515 & $1939-73$ & 35 & 278 & 1.22 & $\begin{array}{l}\text { LD - waste-disposal, } \\
\text { Murray (minor) }\end{array}$ \\
\hline 03610545 & West Fork Clarks River near Brewers & 68.7 & 36.780 & 88.467 & 513 & $\begin{array}{l}1969-83 \\
1990-94\end{array}$ & 20 & 91.5 & 1.33 & -- \\
\hline 03611260 & Massac Creek near Paducah & 14.6 & 37.041 & 88.711 & 436 & $1972-99$ & 28 & 17.4 & 1.19 & - \\
\hline 03611500 & Ohio River at Metropolis, Illinois & 203,000 & 37.148 & 88.741 & -- & $1929-99$ & 71 & 278,000 & 1.37 & Various \\
\hline
\end{tabular}


Table 1. Continuous-record streamflow-gaging stations used in the study, selected basin characteristics, periods of record used in the analysis, corresponding mean annual flows, and selected reservoirs and diversions in the basin for Kentucky and surrounding States-Continued

$\left[\mathrm{mi}^{2}\right.$, square miles; $\mathrm{ft}^{3} / \mathrm{s}$, cubic feet per second; $\mathrm{ft}^{3} / \mathrm{s}^{\mathrm{s}} / \mathrm{mi}^{2}$, cubic feet per second per square mile; --, not applicable; $\mathrm{LD}$, local diversion; all stations are in Kentucky unless otherwise noted]

\begin{tabular}{|c|c|c|c|c|c|c|c|c|c|c|}
\hline $\begin{array}{l}\text { Station } \\
\text { number }\end{array}$ & Station name & $\begin{array}{l}\text { Total } \\
\text { drainage } \\
\text { area } \\
\left(\mathrm{mi}^{2}\right)\end{array}$ & $\begin{array}{c}\text { Gage } \\
\text { latitude } \\
\text { (decimal } \\
\text { degrees) }\end{array}$ & $\begin{array}{c}\text { Gage } \\
\text { longitude } \\
\text { (decimal } \\
\text { degrees) }\end{array}$ & $\begin{array}{c}\text { Mean } \\
\text { basin } \\
\text { elevation } \\
\text { (feet } \\
\text { above } \\
\text { sea level) }\end{array}$ & $\begin{array}{l}\text { Period of } \\
\text { record used } \\
\text { in the } \\
\text { analysis } \\
\text { (water } \\
\text { years }{ }^{1} \text { ) }\end{array}$ & $\begin{array}{c}\text { Number } \\
\text { of } \\
\text { years }\end{array}$ & $\begin{array}{c}\text { Mean } \\
\text { annual } \\
\text { flow } \\
\left(\mathrm{ft}^{3} / \mathrm{s}\right)\end{array}$ & $\begin{array}{c}\text { Standardized } \\
\text { mean annual } \\
\text { flow } \\
\left(\mathrm{ft}^{3} / \mathrm{s} / \mathrm{mi}^{2}\right)\end{array}$ & $\begin{array}{c}\text { Selected reservoirs } \\
\text { in basin and } \\
\text { start date or type of } \\
\text { local diversion and } \\
\text { location }\end{array}$ \\
\hline 03611800 & Bayou Creek at Heath & 6.55 & 37.099 & 88.824 & 422 & $\begin{array}{l}1991 \\
1994-99\end{array}$ & 7 & 6.42 & .98 & -- \\
\hline 03611850 & Bayou Creek near Grahamville & 14.9 & 37.145 & 88.827 & 405 & $\begin{array}{l}1991 \\
1994-99\end{array}$ & 7 & 20.8 & 1.40 & -- \\
\hline 03611900 & Little Bayou Creek near Grahamville & 5.78 & 37.139 & 88.791 & 365 & $\begin{array}{l}\text { 1991, } \\
1994-99\end{array}$ & 7 & 6.59 & 1.14 & -- \\
\hline 03612000 & Cache River at Forman, Illinois & 244 & 37.336 & 88.924 & 491 & $1925-99$ & 75 & 297 & 1.22 & -- \\
\hline 07022500 & Perry Creek near Mayfield & 1.72 & 36.679 & 88.632 & 517 & $\begin{array}{l}1953-65 \\
1968-72\end{array}$ & 18 & 1.78 & 1.03 & - \\
\hline 07023000 & Mayfield Creek at Lovelaceville & 212 & 36.952 & 88.825 & 481 & $1939-72$ & 34 & 231 & 1.09 & -- \\
\hline 07023500 & Obion Creek at Pryorsburg & 36.8 & 36.686 & 88.726 & 496 & $1952-73$ & 22 & 40.1 & 1.09 & -- \\
\hline 07024000 & Bayou De Chien near Clinton & 68.7 & 36.629 & 88.964 & 422 & $\begin{array}{l}1940-78 \\
1985-99\end{array}$ & 54 & 103 & 1.50 & -- \\
\hline 07026500 & $\begin{array}{l}\text { Reelfoot Creek near Samburg, } \\
\text { Tennessee }\end{array}$ & 110 & 36.442 & 89.296 & 391 & $1952-73$ & 22 & 120 & 1.09 & -- \\
\hline
\end{tabular}

${ }^{1}$ Water year refers to the 12 -month period from October 1 through September 30 . The water year is designated by the calendar year in which it ends.

${ }^{2}$ Value adjusted based on correlation of concurrent record with Ohio River at Louisville (03294500)

${ }^{3}$ Value adjusted based on correlation of concurrent record with Ohio River at Metropolis, Ill. (03611500)

${ }^{4}$ Values in the table are for the period after 1966 only-after the Kentucky Lake-Lake Barkley Canal was opened in May 1966. 


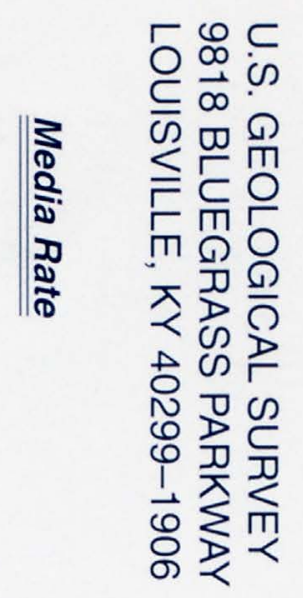

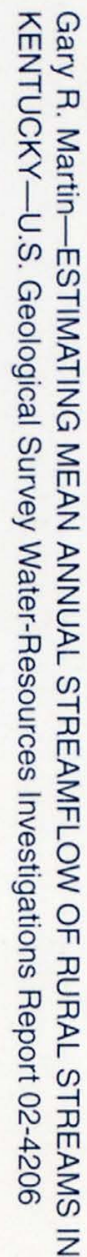

(3) Printed on recycled paper 